\title{
Tracing the effects of eutrophication on molluscan communities in sediment cores: outbreaks of an opportunistic species coincide with reduced bioturbation and high frequency of hypoxia in the Adriatic Sea
}

\author{
Adam Tomašových, Ivo Gallmetzer, Alexandra Haselmair, Darrell S. Kaufman, Martina Kralj, \\ Daniele Cassin, Roberto Zonta, and Martin Zuschin
}

\begin{abstract}
Estimating the effects and timing of anthropogenic impacts on the composition of macrobenthic communities is challenging, because early twentieth-century surveys are sparse and the corresponding intervals in sedimentary sequences are mixed by bioturbation. Here, to assess the effects of eutrophication on macrobenthic communities in the northern Adriatic Sea, we account for mixing with dating of the bivalve Corbula gibba at two stations with high accumulation (Po prodelta) and one station with moderate accumulation (Isonzo prodelta). We find that, first, pervasively bioturbated muds typical of highstand conditions deposited in the early twentieth century were replaced by muds with relicts of flood layers and high content of total organic carbon (TOC) deposited in the late twentieth century at the Po prodelta. The twentieth century shelly muds at the Isonzo prodelta are amalgamated but also show an upward increase in TOC. Second, dating of $C$. gibba shells shows that the shift from the early to the late twentieth century is characterized by a decrease in stratigraphic disorder and by an increase in temporal resolution of assemblages from $\sim 25-50$ years to $\sim 10-20$ years in both regions. This shift reflects a decline in the depth of the fully mixed layer from more than $20 \mathrm{~cm}$ to a few centimeters. Third, the increase in abundance of the opportunistic species C. gibba and the loss of formerly abundant, hypoxia-sensitive species coincided with the decline in bioturbation, higher preservation of organic matter, and higher frequency of seasonal hypoxia in both regions. This depositional and ecosystem regime shift occurred in ca. A.D. 1950. Therefore, the effects of enhanced food supply on macrobenthic communities were overwhelmed by oxygen depletion, even when hypoxic conditions were limited to few weeks per year in the northern Adriatic Sea. Preservation of trends in molluscan abundance and flood events in cores was enhanced by higher frequency of hypoxia that reduced bioturbation in the late twentieth century.
\end{abstract}

Adam Tomašových. Earth Science Institute, Slovak Academy of Sciences, Dúbravska cesta 9, 84005, Bratislava, Slovakia. E-mail: geoltoma@savba.sk

Ivo Gallmetzer, Alexandra Haselmair, and Martin Zuschin. University of Vienna, Department of Palaeontology, Althanstrasse 14, 1090 Vienna, Austria.E-mail: ivo.gallmetzer@univie.ac.at, alexandra.haselmair@univie.ac.at, martin.zuschin@univie.ac.at

Darrell S. Kaufman. School of Earth Sciences \& Environmental Sustainability, Northern Arizona University, Campus Box 4099, Flagstaff, Arizona 86011, USA. E-mail: Darrell.Kaufman@nau.edu

Martina Kralj. Istituto Nazionale di Oceanografia e di Geofisica Sperimentale, via A. Piccard 54, 34014 Trieste, Italy.E-mail:mkralj@inogs.it

Daniele Cassin and Roberto Zonta. Consiglio Nazionale delle Ricerche, Istituto di Scienze Marine, Castello 2737/F, 30122 Venice, Italy. E-mail: daniele.cassin@ve.ismar.cnr.it, roberto.zonta@ve.ismar.cnr.it

Accepted: 29 May 2018

Published online: 16 August 2018

Data available from the Dryad Digital Repository: https://doi.org/10.5061/dryad.84g36m4

\section{Introduction}

Past states in the composition of marine ecosystems can be reconstructed on the basis of sediment cores (Yasuhara and Yamazaki 2005; Pandolfi and Jackson 2006; Gooday et al. 2009; Cramer et al. 2012; Kowalewski et al. 2015; Price et al. 2018). However, the interpretation of ecosystem baselines on the basis of Holocene stratigraphic archives faces challenges due to (1) stratigraphic mixing (Walbran et al. 1989; Loubere and Gary 1990; Bentley and Sheremet 2003; Kosnik et al. 2007) and (2) differences in the type of sedimentary records preserved in transient mixed layers and permanent subsurface layers 
(Wheatcroft and Drake 2003; Bentley et al. 2006; Löwemark et al. 2008; Tomašových et al. 2014). In contrast to archives formed by laminated sediments under anoxic conditions, bioturbated increments do not map to discrete sediment age but rather summarize the central tendency of age-frequency distributions of sedimentary particles (Kowalewski et al. 1998; Tomašových and Kidwell 2010; Johannessen and Macdonald 2012). Understanding the effects of mixing is particularly important in assessments of ecosystems subjected to perturbations occurring at temporal scales shorter than scales of sediment aggradation (Lotze et al. 2006; Willis et al. 2007; Kidwell 2015) and in evaluation of preservation of stratigraphic markers that can define the onset of major anthropogenic signals in the sedimentary record (Wolfe et al. 2013). Such assessments frequently require annual, decadal, or subcentennial resolution.

Assuming relatively high sedimentation rates close to $1 \mathrm{~cm} / \mathrm{yr}$, that is, values close to the upper estimates of sedimentation rates on continental shelves (Sommerfield 2006), the twentieth-century sedimentary record will be captured in 100-cm-long sediment cores. Such thickness is frequently affected by bioturbation reaching several decimeters or even a few meters below the sediment-water interface (Bentley and Nittrouer 2012; Parsons-Hubbard et al. 2014). Stratigraphic patterns can be deconvolved to pre-bioturbation signals (Hull et al. 2011; Steiner et al. 2016) but such approaches require information on depthdependent changes in bioturbation and can be limited under very slow sedimentation rate and high mixing (Schiffelbein 1985). However, dating a large number of shells, for example, by amino acid racemization calibrated by radiocarbon (Allen et al. 2013; Kosnik et al. 2015), allows us to determine the age-frequency distribution (AFD) in any stratigraphic increment. The AFD is a function of shell loss (driven by shell disintegration and/or by shell movement to underlying or overlying increments) and production (Tomašových et al. 2016), and it can be used not only to determine temporal resolution of assemblages in stratigraphic increments (Flessa and Kowalewski 1994; Kidwell et al. 2005; Scarponi et al. 2013) but also to detect changes in production occurring at a temporal resolution finer than the resolution of stratigraphic increments (Tomašových and Kidwell 2017; Tomašových et al. 2017).

Eutrophication is one of the major anthropogenic impacts affecting marine benthic communities (Rabalais et al. 2009). More abundant food supply driven by eutrophication can promote growth of benthic fauna in open ocean-facing ecosystems with sufficient circulation (Beukema and Cadée 1991), but can also enhance or trigger hypoxia or anoxia in ecosystems susceptible to stratification (Breitburg et al. 2018). Here, we assess the effects of eutrophication on the composition and functioning of macrobenthic communities in the northern Adriatic Sea (Fig. 1), which is prone to seasonal water-column stratification. We evaluate the timing of shifts in abundance of the opportunistic bivalve Corbula gibba in sediment cores, test whether these shifts correlate with concentrations of dissolved oxygen, and assess whether temporal changes in bioturbation can be detected by down-core trends in time averaging and stratigraphic disorder. We follow Gofas (2008) in using the genus name Corbula, although Anderson and Roopnarine (2003) suggested that the valid genus name of this species is Varicorbula. This species presently dominates in molluscan communities in the NE and NW Adriatic Sea (Aleffi and Bettoso 2000; N'Siala et al. 2008; Mavric et al. 2010; Nerlović et al. 2011, 2012; Franzo et al. 2015). It tolerates sediment pollution and is able to survive seasonal hypoxic crises (Diaz and Rosenberg 1995; Riedel et al. 2012). Therefore, assemblages with high abundances of C. gibba can represent tracers of natural or anthropogenic disturbance over the past 500 years (Tomašových et al. 2017) or over longer timescales (Dominici 2001; Zuschin et al. 2007, 2014; Scarponi and Kowalewski 2004). In this study, we focus on the twentieth century, when a major increase in eutrophication and the frequency of hypoxic and mucilage events is documented by historical data from the northern Adriatic Sea (Fig. 2; Marchetti et al. 1989; Harding et al. 1999; Justić 1991) and worldwide (Carstensen et al. 2014; Breitburg et al. 2018). Although the twentieth-century increase in eutrophication in the northern Adriatic Sea (Barmawidjaja et al. 1995; Notar et al. 2001; 

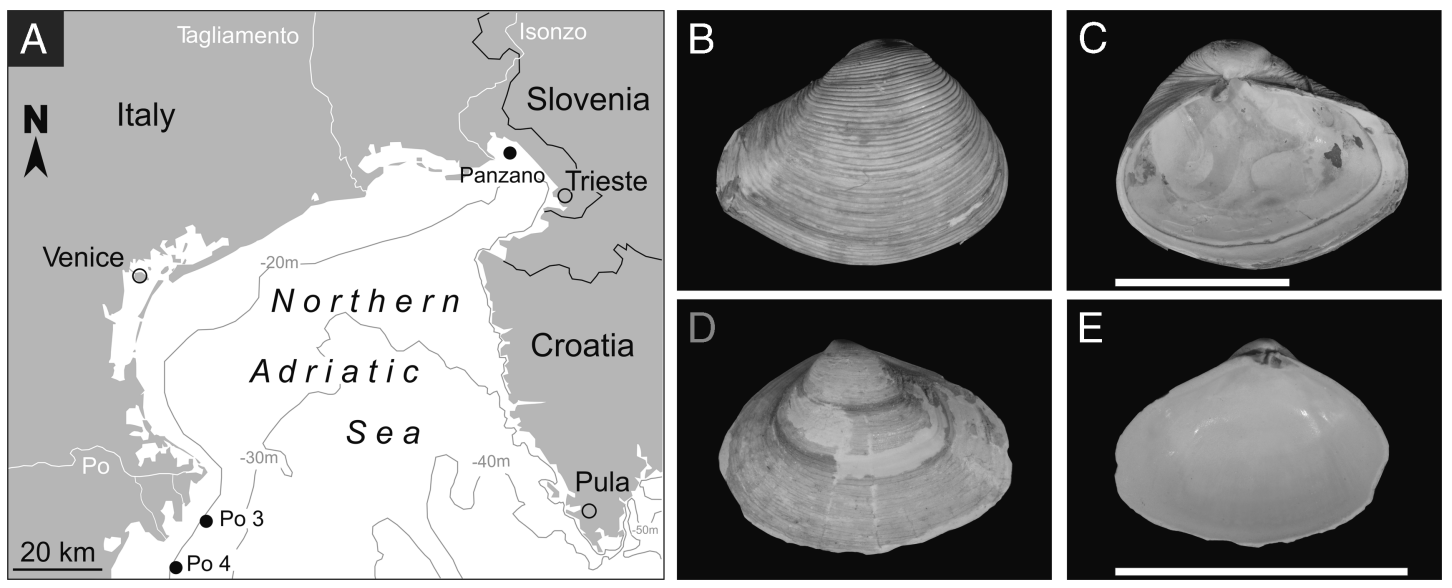

Figure 1. (A), Location of two stations at $21 \mathrm{~m}$ depth at the Po prodelta (Po 3 and Po 4 ) and one station at $12 \mathrm{~m}$ depth in the Bay of Panzano at the Isonzo prodelta (Panzano). External and internal surfaces of a right valve (B, C, UAL11620) and left valve (D, E, UAL11616) of Corbula gibba collected at 4-6 cm sediment depth at Po 4 . Scale bar: $5 \mathrm{~mm}$.

A

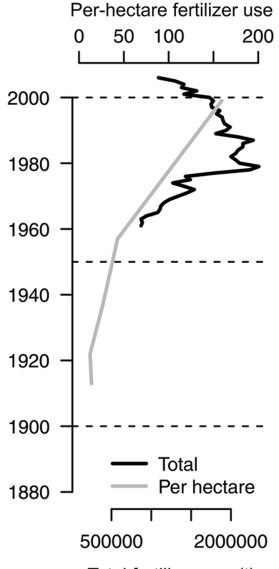

$B$

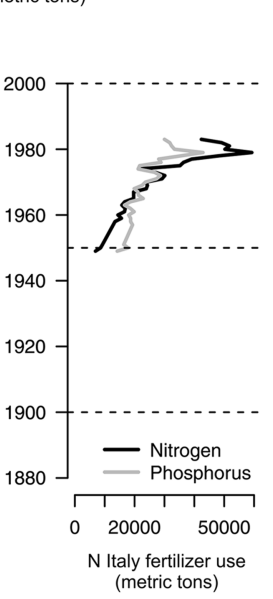

C

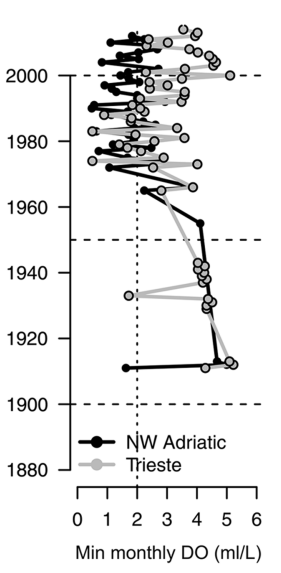

D

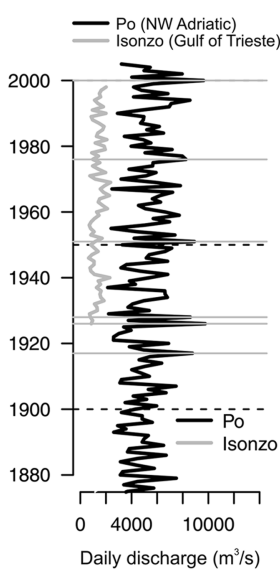

$E$

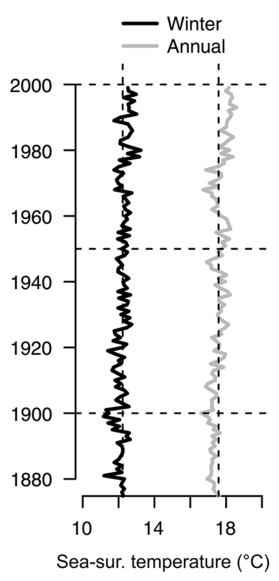

FIGURE 2. The history of eutrophication in the northern Adriatic Sea, with total fertilizer use in Italy (A), northern Italy use of nitrogen and phosphorus (B), minimum monthly dissolved oxygen concentrations (C), maximum daily discharge of the Po and Isonzo Rivers (D), and sea-surface temperature (E). The gray horizontal lines in D refer to years with major flood events of the Po River when daily discharge exceeded $8000 \mathrm{~m}^{3} / \mathrm{s}$. The total fertilizer use in Italy between 1961 and 2006 is from an online data set of agriculture statistics (NationMaster 2018), the fertilizer use per hectare (kg of nutrients) is from Federico and Malanima (2004), and the fertilizer use in northern Italy is from Justić (1991). The sources of other data are explained in "Methods."

Sangiorgi and Donders 2004; Zonneveld et al. 2012) was followed by an oligotrophization trend since the 1990s (Cozzi et al. 2012; Giani et al. 2012; Djakovac et al. 2015), hypoxic and mucilage events also affected the northern Adriatic Sea in the earliest twenty-first century (Alvisi and Cozzi 2016; Cibic et al. 2012).

Long-term records of nutrient concentrations, phytoplankton biomass, and primary productivity in the northern Adriatic Sea are available mainly for the second half of the twentieth century (Degobbis et al. 2000; Giani et al. 2012). Therefore, it is unclear what oceanographic and trophic conditions characterized this region in the early twentieth century. Crema et al. (1991) and Chiantore et al. (2001) suggested that soft-bottom macrobenthic communities shifted toward the dominance of opportunistic species during the twentieth century. However, the early 
twentieth-century survey data of macrobenthic communities are limited before the 1960s (Vatova 1935, 1949), and analyses of the early and late twentieth-century surveys are compromised by differences in sampling protocol and mesh size (Scardi et al. 2000). Here, we specifically test whether this temporal shift in the composition of macrobenthic communities based on monitoring of living assemblages can be validated on the basis of sediment cores and whether it can be attributed to eutrophication. Tomašových et al. (2017) and Gallmetzer et al. (2017) analyzed changes in the composition of molluscan communities in 1.5-m-long sediment cores over the past $\sim 500$ years in the Gulf of Trieste (see also Vidović et al. [2016] for changes in foraminiferal assemblages). Here, we focus solely on the twentiethcentury portion of these sediment cores from the Isonzo prodelta (NE Adriatic), and expand our spatial coverage to the Po prodelta (NW Adriatic) by adding sediment cores from two other sampling stations that cover the twentieth-century period, and thus assess temporal changes both in the NE and NW Adriatic Sea.

First, we estimate sedimentation rates and mixing with (1) sediment ${ }^{210} \mathrm{~Pb}$ and (2) radiocarbon-calibrated amino acid racemization (AAR) of shells and test whether disorder and temporal resolution differ between sediments deposited before (early twentieth century) and after the onset of major eutrophication (late twentieth century). Second, we evaluate stratigraphic trends in the composition of molluscan assemblages. Third, we compare raw stratigraphic trends in the absolute and proportional abundance of $C$. gibba with abundance trends of unmixed age cohorts, reconstructed on the basis of downcore changes in the shape of postmortem AFDs. Fourth, we compare the abundance records with historical trends in the concentration of dissolved oxygen (Justić et al. 1987; Djakovac et al. 2015). We also evaluate other mechanisms that can promote outbreaks of $C$. gibba, including (1) fluctuations of river discharge, because sediment deposited during major river floods can increase sediment instability; and (2) sea-surface temperature as an index of regional climate. Warming can prolong water-column stratification (Malej and Malacic 1995) and increase the probability of mucilage events, and thus can increase the probability of benthic mass-mortality events (Stachowitsch 1984; Coma et al. 2009).

\section{Methods}

Setting and Sampling.-We analyze sediment cores collected at three stations in 2013, with two stations located in the Po prodelta in the NW Adriatic, and one station in the Isonzo prodelta in the Gulf of Trieste in the NE Adriatic. These two deltaic systems are characterized by the highest sediment accumulation rates in the northern Adriatic Sea (Frignani et al. 2005; Covelli et al. 2006) and thus can represent highresolution stratigraphic archives (Scarponi and Kowalewski 2007; Wittmer et al. 2014). All stations represent soft-bottom, nonvegetated, oligophotic to aphotic habitats affected by high turbidity. Station Po $3\left(44.842183^{\circ} \mathrm{N}, 12.538833^{\circ}\right.$ E) is located at $21 \mathrm{~m}$ depth, west of the Po di Tolle lobe of the Po River delta. South of Po 3, Station Po $4\left(44.730533^{\circ} \mathrm{N}, 12.440217^{\circ} \mathrm{E}\right)$ is located at $21 \mathrm{~m}$ depth, southeast of the GoroGnocca lobe. Station Panzano is located in the Isonzo prodelta in the northern Gulf of Trieste at $12 \mathrm{~m}$ water depth $\left(45.735400^{\circ} \mathrm{N}, 13.600467^{\circ} \mathrm{E}\right)$ (Fig. 1). The seafloor at the Po prodelta is affected by decadal-scale deposition of few laminated, centimeter-thick flood layers (Tesi et al. 2011, 2012). At our two stations, the seafloor is formed by muds with high abundance of mounds generated by the thalassinid shrimp Jaxea nocturna and by worm tubes of the polychaete Sabella pavonina (Fig. 3A-C). The seafloor at Panzano in the northern Gulf of Trieste is characterized by muds with abundant epifaunal clumps formed by sponges, ascidians, ophiurids, polychaetes, and bivalves (Fig. 3D; Zuschin and Stachowitsch 2009).

Four closely positioned cores, $150-155 \mathrm{~cm}$ long, were sampled at each station in 2013 with an UWITEC $^{\circledR}$ piston corer (Gallmetzer et al. 2016). Changes in abundance of C. gibba were measured in two 16-cm-diameter cores at each station (M13 and M14 cores at Po 3, M20 and M21 cores at Po 4, and M28 and M29 cores at Panzano). The other two cores with $9 \mathrm{~cm}$ 

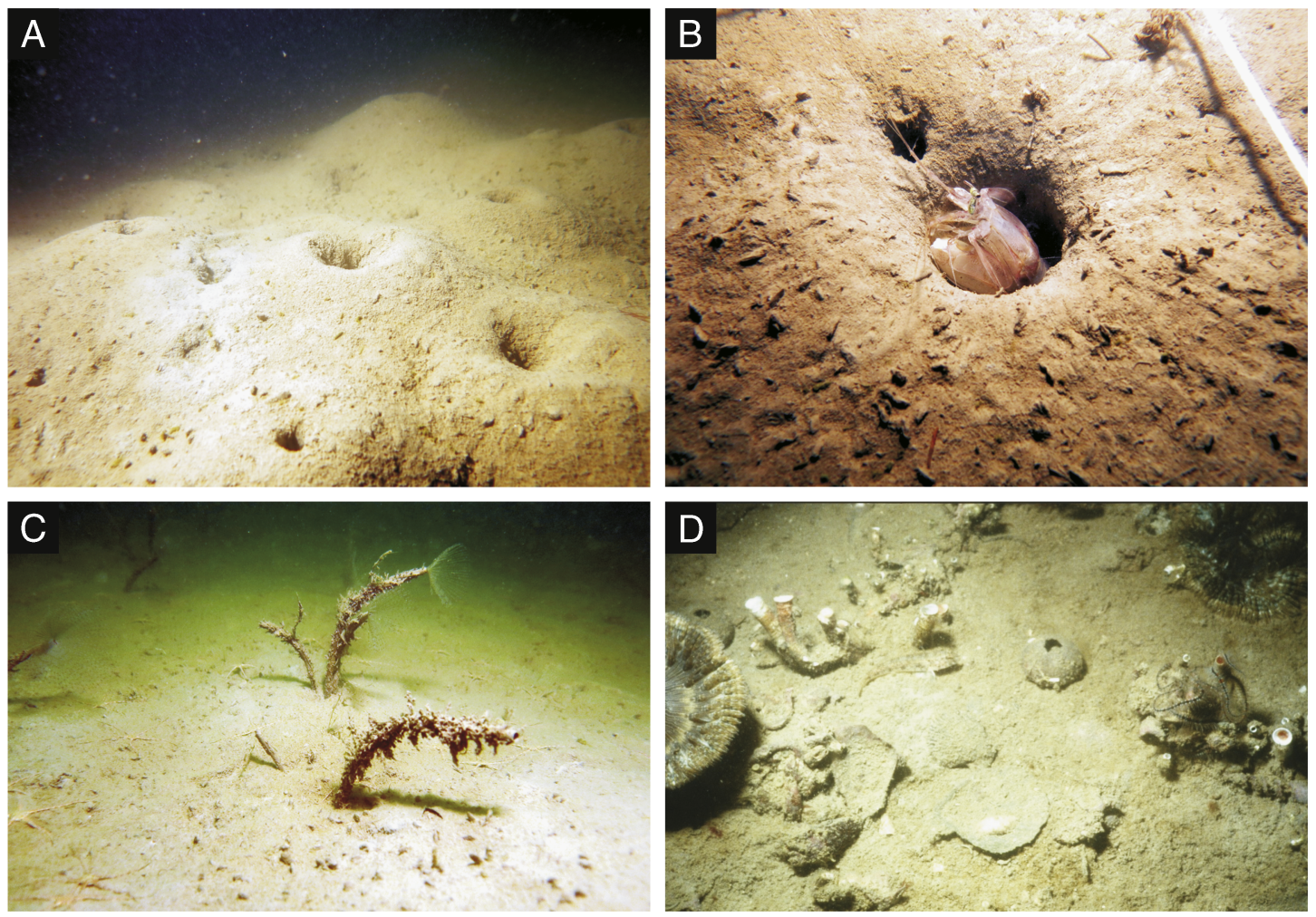

FigURE 3. Bottom conditions typical of the two areas. The muddy seafloor at the Po prodelta is formed by frequent mounds of the shrimp Jaxtea nocturna at Po $3\left(\sim 1 \mathrm{~m}^{2}\right.$ of seafloor is covered in A and the close-up of the burrow is $\sim 25 \mathrm{~cm}^{2}$ in B) and by tube-dwelling polychaete worms Sabella pavonina sticking up 10-12 cm above the sediment at Po 4 (C). D, The muddy seafloor in the Bay of Panzano with shelly debris and epifaunal clumps with polychaetes, anemones, and ophiuroids an area of about $15 \times 25 \mathrm{~cm}$. A-C, Photographs by Ivo Gallmetzer and Alexandra Haselmair; D, photograph by Michael Stachowitsch.

diameter were used for measurements of ${ }^{210} \mathrm{~Pb}$ activities in bulk sediment and for measurements of concentrations of total organic content (TOC) and total nitrogen (TN). Ages of C. gibba were assessed in cores M13 and M21 (this study) and in M28 (Tomašových et al. 2017). Molluscan shells were sieved with a $1 \mathrm{~mm}$ mesh size. All bivalves and gastropod specimens with hinge line or apex preserved were counted and identified to the species level. In bivalves, abundance was calculated by adding the number of doublevalved specimens to whichever number of single valves (right or left) was higher. In chitons, abundance was estimated by adding the higher number of terminal plates to the number of dorsal plates divided by six. For scaphopods, the number of entire individuals was added to the higher number of apex or base fragments (Gallmetzer et al. 2017). We assess the relation between absolute and proportional abundances of C. gibba and concentrations of TOC and TN with partial Spearman rank correlation and with generalized least-square models, modeling the temporal structure of residuals with the autoregressive process of order 1 (Beguería and Pueyo 2009). We evaluate stratigraphic changes in the composition of communities on the basis of square-root-transformed proportional abundances of molluscan species (other than Corbula gibba) and Bray-Curtis dissimilarities with nonmetric multidimensional scaling (NMDS). We exclude the bivalve Anadara transversa, which immigrated to the northern Adriatic Sea in the 1970s (Albano et al. 2018), and test differences in species composition between the early and late twentieth-century communities with nonparametric permutational multivariate analysis of variance (PERMANOVA; Anderson 2001). 
${ }^{210} \mathrm{~Pb}$, Amino Acid Racemization, and Radiocarbon Calibration.-Activities of ${ }^{210} \mathrm{~Pb}$ and ${ }^{226} \mathrm{Ra}$ were analyzed in 2 -cm-thick increments in the upper $20 \mathrm{~cm}$ and in $5-\mathrm{cm}-$ thick increments between 20 and $40 \mathrm{~cm}$ by gamma spectrometry with a high-purity germanium detector system (Supplementary Table 1). AAR analysis was carried out at Northern Arizona University using reversephase high-pressure liquid chromatography (Kaufman and Manley 1998). Tomašových et al. (2017) presented calibration of AAR in C. gibba shells by ${ }^{14} \mathrm{C}$ on the basis of 11 dead shells and 3 live-collected shells from the Gulf of Trieste, with the time-dependent reaction kinetic model (TDK; Allen et al. 2013) for aspartic acid (Asp) D/L (ratio of dextrorotatory and levorotatory enantiomers), being the best model (Fig. 4A), with the initial $\mathrm{D} / \mathrm{L}$ value estimated from data (TDK1). The calibration equation is:

$$
a * \operatorname{arctanh}\left(\left[\mathrm{DL}-\mathrm{DL}_{0}\right] /\left[1-\mathrm{DL} * \mathrm{DL}_{0}\right]\right)^{b}
$$

where DL is Asp D/L, DL 0 is Asp D/L at 0 years (here, 0.028), $a=87855.52$, and $b=2.531196$. The uncertainty is defined by the log-normal distribution, with the mean equal to the age estimate and the variance equal to 0.056 . Using the uncertainty defined by the gamma distribution, the simple power-law kinetic model for Asp D/L, with the initial
$\mathrm{D} / \mathrm{L}$ value fixed at 0 , was the best model (Fig. 4B). Although shells from the Po prodelta were not used in the calibration, (1) the bottomwater temperatures at $\mathrm{Po}$ and Isonzo prodeltas are very similar, with mean monthly temperatures ranging between $8^{\circ} \mathrm{C}$ and $28^{\circ} \mathrm{C}$ in both regions (Gacic et al. 1999), and (2) our calibration equation closely correlates with the results from Scarponi et al. (2013), who calibrated AAR of C. gibba independently on the basis of five shells from the Po delta (Fig. $4 C)$. Thirty specimens were selected at random from 12 to 14, approximately equally spaced increments of M13, M21, and M28 cores, or all specimens were selected if the total number of specimens was smaller. Thirteen specimens at M13, 14 specimens at M21, and 18 specimens at M28 were flagged as outliers according to screening criteria of Kosnik and Kaufman (2008) and were removed from analyses. In total, 252 shells of C. gibba from 14 increments in M13 and 243 shells from 14 increments in M21 were used in analyses. AAR data of shells from the two Po cores are presented here for the first time. AAR data of 311 shells from 12 increments in M28 were presented by Tomašových et al. (2017). All amino acid data and shell ages are listed in Supplementary Table 2.

Sedimentation Rate.-The fully mixed layer (FML) refers here to a stratigraphic interval
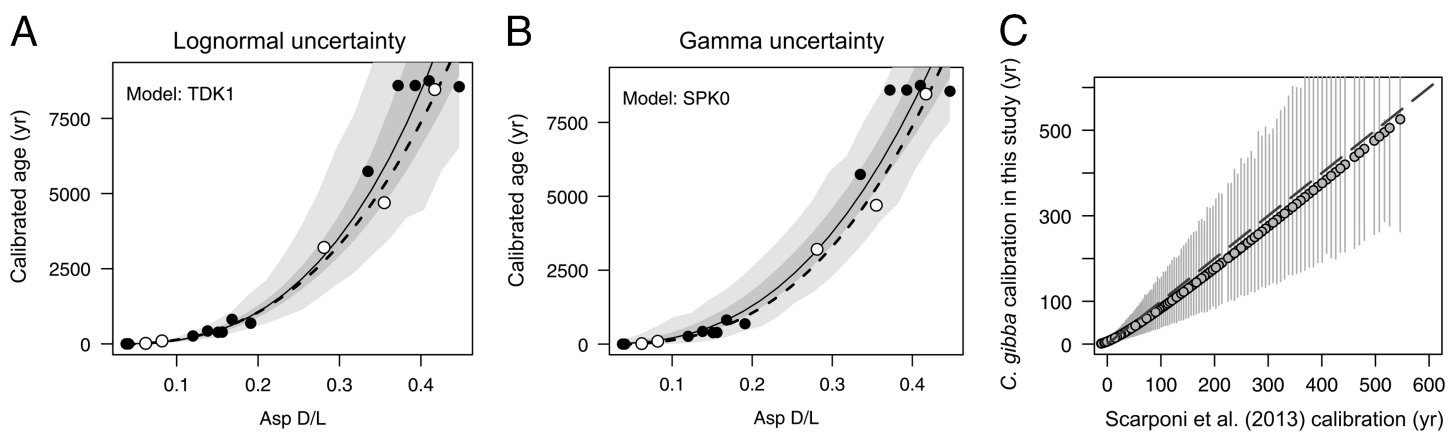

FIGURE 4. A and B, Relation between postmortem age (determined by ${ }^{14} \mathrm{C}$ ) and $\mathrm{D} / \mathrm{L}$ values of aspartic acid (Asp) for Corbula gibba, best fit by TDK1 (time-dependent reaction kinetics) and SPK0 (simple power-law kinetics with the initial $\mathrm{D} / \mathrm{L}$ value fixed at zero) models, respectively, on the basis of Bayesian information criterion, and assuming that uncertainty follows the log-normal (A) and the gamma distributions (B). Black points refer to 11 dead shells and 3 livecollected shells from the Gulf of Trieste that were used in our calibration. White points refer to five individuals from the Po delta dated by Scarponi et al. (2013). Light-gray shading corresponds to $95 \%$ prediction intervals for the age of a given specimen; dark-gray shading corresponds to $95 \%$ confidence intervals for median age. Five shells with the oldest ages were collected in a sediment core sampled in the Bay of Piran. In C, calibration of Scarponi et al. (2013) based on Asp D/L of C. gibba shells from the Po delta correlates closely with calibration used in this study. Error bars correspond to $95 \%$ prediction intervals. 
where 2- or 4-cm-thick core increments do not differ in median age of shells (surface-mixed layer; Wheatcroft et al. 2007). The maximum depth of bioturbation is typically below the FML. The FML is age homogenized and thus cannot be used for estimation of sedimentation rates. We assess net sedimentation rates by (1) estimating the slope of the decay in excess ${ }^{210} \mathrm{~Pb}$ between 20 and $90 \mathrm{~cm}$ at $\mathrm{Po}$ and between 6 and $30 \mathrm{~cm}$ at Panzano (i.e., down to the appearance of background levels) according to the constant flux-constant sedimentation model (Sanchez-Cabeza and Ruiz-Fernández 2012) and (2) dividing the sediment thickness by the median age of $C$. gibba at the sediment depth comparable to ${ }^{210} \mathrm{~Pb}$ dating (at $85 \mathrm{~cm}$ at Po and at $35 \mathrm{~cm}$ at Panzano).

Time Averaging and Disorder.-We estimate time averaging with the interquartile range (IQR) of C. gibba ages in (1) three 20- to 70-cmthick stratigraphic units defined according to sedimentologic and geochronological criteria (units 1-3) and (2) 4- or 5-cm-thick increments. The three units correspond to (1) the early twentieth century (lower unit 1), (2) the late twentieth century (middle unit 2), and (3) the earliest twenty-first century (upper unit 3). Age uncertainty associated with calibrating the rate of AAR increases with age (Yanes et al. 2007). Therefore, we compute the component of time averaging expected purely due to the calibration error by estimating an IQR for each shell under a repeated sampling of shell ages from log-normal distribution, with the mean determined by the calibrated shell age and the standard deviation determined by the fit of age data to the TDK1 model. Dominguez et al. (2016) and Ritter et al. (2017) sampled shell ages from a posterior distribution generated from the product of a likelihood function of the log-normal distribution (or gamma distribution, depending on the calibration) and a noninformative prior distribution; the results of these two approaches are very similar. The mean IQR of all shells in a given increment represents the component of time averaging expected purely under calibration error. The time averaging corrected for this error refers to the difference between the raw IQR on one hand and the error component on the other hand
(Dominguez et al. 2016). We estimate stratigraphic disorder (Cutler and Flessa 1990) by correlating shell ages with sediment depth of corresponding shells, using Spearman correlation. We compute correlations within three stratigraphic units at Po 3 and Po 4 (corresponding to the early twentieth century, late twentieth century, and the earliest twentyfirst century, respectively), and within two units at Panzano (the earliest twenty-first century is represented in one increment only).

To infer differences in bioturbational mixing before and after the major eutrophication phase, we test whether time averaging and disorder differ in sediments deposited during the early (unit 1) and late twentieth century (unit 2). In this case, we filter out the effect of postdepositional mixing. For example, individuals that died after A.D. 2000 can be reworked to unit 2, initially deposited during the late twentieth century. Therefore, when computing time averaging and disorder of shells induced by syndepositional mixing in sediments of unit 1 (deposited during the early twentieth century), we exclude shells that are younger than the oldest median age of the overlying unit 2 . When computing time averaging and disorder of shells in sediments of unit 2 deposited during the late twentieth century, we exclude shells that are younger than the oldest median age of unit 3. Although this procedure still does not exclude the effect of postdepositional reworking of shells from unit 1 to unit 2, such estimates provide first-order estimates of syndepositional mixing during the early and late twentieth century. In this case, we do not apply the calibration error correction, because this procedure excludes the youngest subset of shell ages.

Reconstructing Abundances of Age Cohorts.The shape of the AFD in the whole core is a function of the number of shells produced during deposition, shell disintegration rate, and shell burial rate (Olszewski 2004; Tomašových et al. 2016, 2017), with the latter two processes representing loss rates because they remove shells from the core. To distinguish the contribution of loss to the shape of the AFD from the contribution of shell production, frequencies of age cohorts in the core are subdivided by a so-called survival 
function that accounts for the magnitude of loss and for the dependence of loss on shell age and/or shell depth in sediment (Tomašových et al. 2016). Estimates of burial and disintegration are needed to approximate this function. Here, first, we estimate top-core burial rates on the basis of ${ }^{210} \mathrm{~Pb}$ profiles and down-core changes in median shell ages. Second, we approximate disintegration rates by subtracting these estimates of core-top burial rates from overall rates of shell loss from the taphonomic active zone (TAZ). Shell loss rates are based on fitting of AFDs from the uppermost few centimenters of the cores to three likelihood models with survival functions that assume steady-state production during the deposition of the FML (Tomašových et al. 2014). We assume the thickness of TAZ is equivalent to the FML thickness (Berkeley et al. 2007; Tomašových et al. 2014).

To unmix the stratigraphic record of $C$. gibba, we account for mixing in the two steps and for shell loss by burial in the third step as implemented in Tomašových et al. (2017). First, we approximate the shape of AFDs of undated increments within the three stratigraphic units by pooling AFDs of dated increments below and above the undated increment into a single AFD. The temporal separation of median ages between directly dated increments is smaller than time averaging of these increments. AFDs in individual increments below the FML are normal shaped, allowing us to fit the shape of the pooled AFD to a normal distribution truncated on the lower interval equal to zero (Jackson 2011) and estimate its mean and standard deviation. Second, we resample specimens to the total number of C. gibba in each increment (Supplementary Table 3), either from incrementspecific empirical AFDs or from interpolated normal distributions, and count the number of resampled specimens in 10-year cohorts. The number of resampled $C$. gibba specimens in each increment is based on the sum of the $C$. gibba specimens in both cores sampled at each station. The resulting distribution of shell specimens in all increments represents the absolute abundances of all specimens in both cores at each station.
Third, when estimating the shell loss rate from the FML, a one-phase exponential model, assuming that the loss rate of shells does not change with shell age and/or with the depth of burial within the FML, performs best relative to more complex models (on the basis the Akaike information criterion). The model fit shows that the loss rate of shells from the FML is similar to the burial rate estimated on the basis of ${ }^{210} \mathrm{~Pb}$ dating and down-core changes in shell median age. Therefore, disintegration rate is probably much smaller than the burial rate at all three stations. We thus assume that disintegration rate can be neglected and that temporal changes in production can be assessed primarily by accounting for burial of shells to depths below $155 \mathrm{~cm}$ (i.e., core length). We thus divide the whole-core AFD (as reconstructed in the first two steps described earlier) by the survival function of the exponential model (i.e., the probability that the shell will survive beyond a given postmortem age, Tomašových et al. 2016), where the parameter $\lambda$ corresponds to the inverse of mean age of shells in the oldest increment $(\lambda=0.0094$ at Po $3, \lambda=0.0089$ at Po 4, $\lambda=0.0028$ at Panzano). Repeating these three steps 1000 times and pooling ages into 10-year cohorts generate an estimate of mean abundance of C. gibba per 10-year cohort per $0.04 \mathrm{~m}^{2}$ (i.e., surface area of two cores at each station). We compare these unmixed reconstructions with stratigraphic trends in abundance of C. gibba directly observed in sediment cores but obscured by mixing. Finally, to translate abundances in 10-year cohorts to yearly standing density, an estimate of per-individual life span is necessary. Corbula gibba lives for $\sim 5$ years (Jones 1956), and Tomašových et al. (2017) used this value to estimate the standing density per square meter. Here, we use this estimate of 5 years and a smaller estimate of 2 years (Hrs-Brenko 2006), which can account for high juvenile mortality, and compare both estimates with densities observed in surveys of living assemblages. The unmixing procedure is described in the Supplementary Material in R language source code.

Historical Environmental and Ecological Data.-We compiled information on standing density of C. gibba sampled mainly by Van Veen grabs and processed with $1 \mathrm{~mm}$ mesh 
size from published sources, covering the NW Adriatic shelf between Po and Pesaro (Aleffi and Bettoso 2000; Occhipinti-Ambrogi et al. 2002, 2005; Simonini et al. 2004) and the northern and central Gulf of Trieste (Orel and Mennea 1969; Solis-Weiss et al. 2004). The early twentieth-century surveys are represented by the data of Vatova (1949). Although there are methodological differences with later surveys, they can provide order-of-magnitude information on $C$. gibba abundance in the early twentieth century. Minimum monthly concentrations of bottom-water dissolved oxygen for the NW Adriatic for the years 1911-1984 were extracted from the western sector of Justic et al. (1987) and for the years 1972-2012 from stations SJ101 and SJ108 of Djakovac et al. (2015) (Fig. 2C). For the Gulf of Trieste, concentrations of bottom-water dissolved oxygen for the years 1911-1984 were extracted from Fedra et al. (1976), Faganeli et al. (1985), from the northern sector of Justić et al. (1987), and from four stations (A, AA1, C3, C323) located at 22, 20, 19, and $18 \mathrm{~m}$ depth in the Gulf of Trieste, respectively (Fig. 2C). Po and Isonzo maximum daily discharge data are based on Zanchettin et al. (2008) and Siché and Arnaud-Fassetta (2014), respectively (Fig. 2D). Annual mean sea-surface temperature data since 1860 (Fig. 2E) were extracted from the Hadley Centre Sea Ice and Sea Surface Temperature data set (Rayner et al. 2003). We assess the effects of these environmental variables averaged to 10 years (dissolved oxygen concentrations, daily discharge, and sea-surface temperature) on unmixed abundances of C. gibba in 10-year cohorts with partial Spearman rank correlations and generalized least-squares (modeling autocorrelation structure according to autoregressive process of order 1).

\section{Results}

\section{Down-Core Changes in Stratification.-} Sediments at all stations are composed of clay and silt, and their proportions remain constant up core (mean proportion of silt is $61 \%$ at Po 3 , $55 \%$ at Po 4 , and $52 \%$ at Panzano). Both Po cores can be subdivided into three major units that differ in sediment density in X-ray radiographs, in the degree of stratification, and in the intensity of bioturbation (Fig. 5): (1) Unit 1 is $70 \mathrm{~cm}$ thick with indistinct, poorly delineated, mottled ichnofabric in the lower part. Distinct layers with sharp boundaries are not preserved. A dense, fuzzy, and irregular lensoid layer occurs at $125-130 \mathrm{~cm}$ in both cores and separates this unit into subunits 1 and 2. Large, $\sim 5$-cm-thick horizontally oriented, poorly delineated burrows produced by echinoderms are preserved in this unit at Po 3. (2) Unit 2 is $60-65 \mathrm{~cm}$ thick and contains dispersed but distinct burrows and 1- to 2-cm-thick, discontinuous, dense, locally laminated layers. These relictual layers are located at $75-85 \mathrm{~cm}$ (bottom of unit 2), at $\sim 50 \mathrm{~cm}$ at both Po stations and at $30-35 \mathrm{~cm}$ at Po 3 and Po 4. The layer at $50 \mathrm{~cm}$ separates this unit into subunits 3 and 4 . Several trails of vertically and obliquely oriented echinoderm burrows $(2-3 \mathrm{~cm}$ in diameter), similar to Bichordites with distinct transversal ribs and a central channel, are visible in X-ray radiographs in subunit 3 at both Po stations (Fig. 5). They penetrate through the relictual layer at $50 \mathrm{~cm}$ and thus postdate its deposition. They are also preserved in subunit 4 at Po 4. (3) The top 16$20 \mathrm{~cm}$ at Po 3 and Po 4 (unit 3 ) are structureless, without distinct burrows, and bounded on the base by a relictual layer (bright in X-ray radiographs) at Po 3. X-ray radiographs from Panzano do not show relicts of episodic sedimentation, and the upper $6 \mathrm{~cm}$ are structureless in radiographs (Fig. 5). The upper $35 \mathrm{~cm}$ of sediment at Panzano are shelly, with frequent shells of Aporrhais, Turritella, and scallops (Aequipecten and Flexopecten). On the basis of age data, 14$35 \mathrm{~cm}$ corresponds to unit 1 (early twentieth century), $6-14 \mathrm{~cm}$ to unit 2 (late twentieth century), and 0-6 cm to unit 3 (FML).

Down-Core Changes in Shell Age.-Median ages of increments at both Po stations decline monotonically from the top (unit 3) down to the upper part of unit 1 , to $100 \mathrm{~cm}$ at $\mathrm{Po} 3$ and to $90 \mathrm{~cm}$ at Po 4, spanning from A.D. 2000 to A.D.1924 at Po 3 and A.D.1934 at Po 4 (Fig. 6). Within this interval at both Po stations, median ages of AFDs remain within the bounds of the upper and lower age quartiles of overlying and 


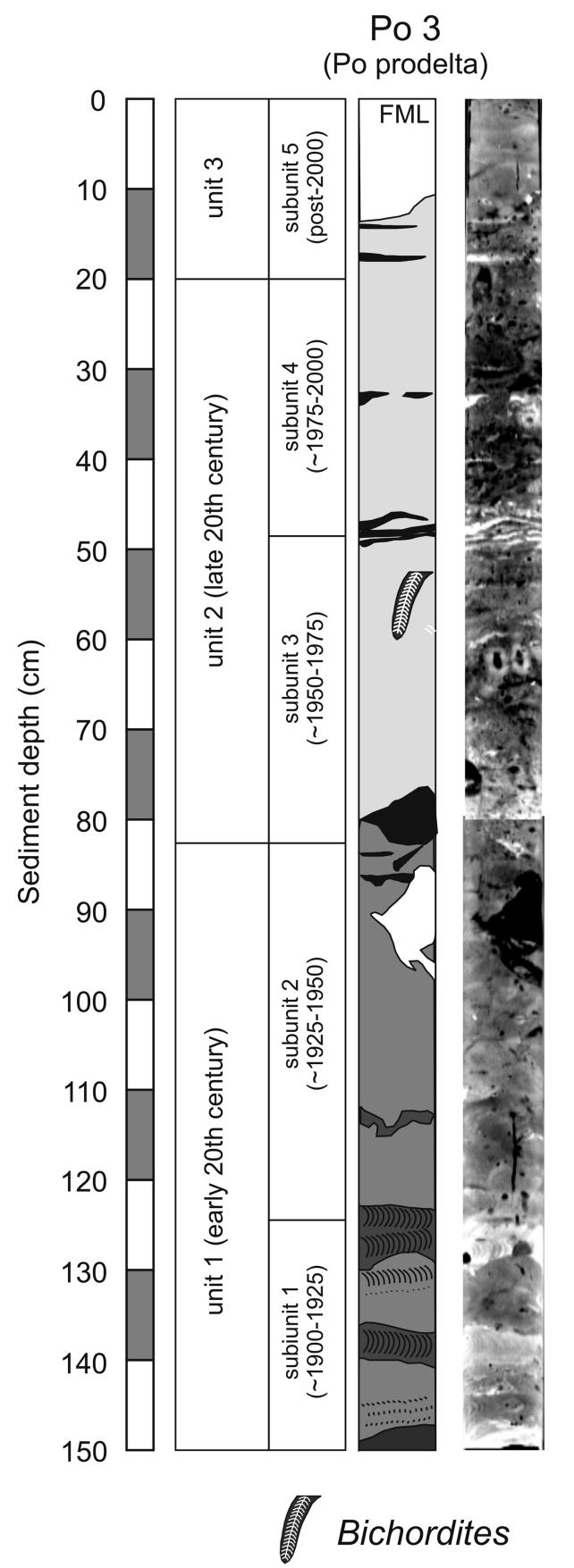

\section{Po 4 \\ (Po prodelta)}
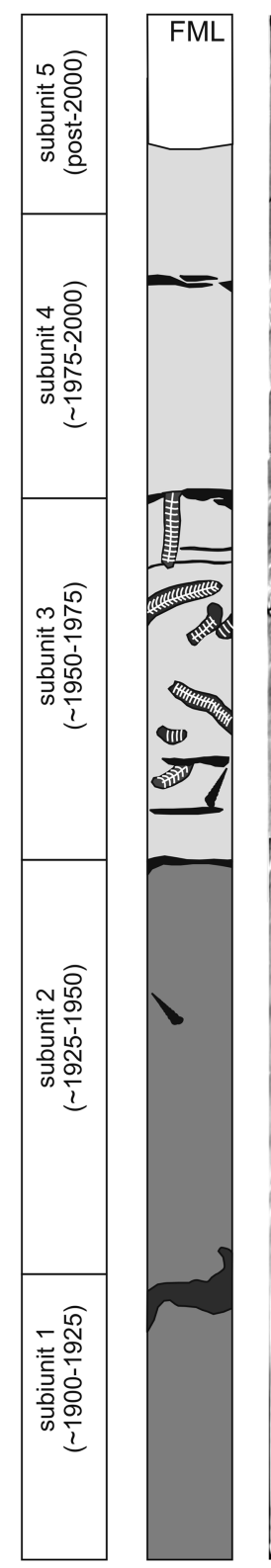
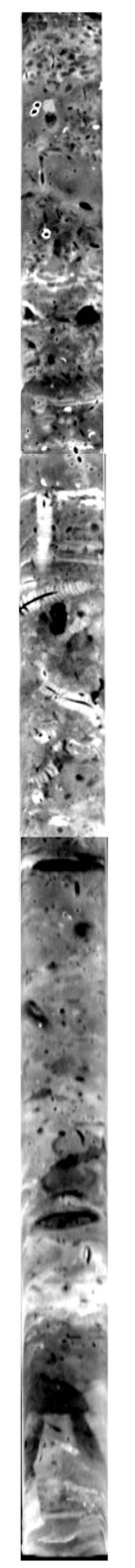

flood layer relicts
Panzano (Isonzo prodelta)

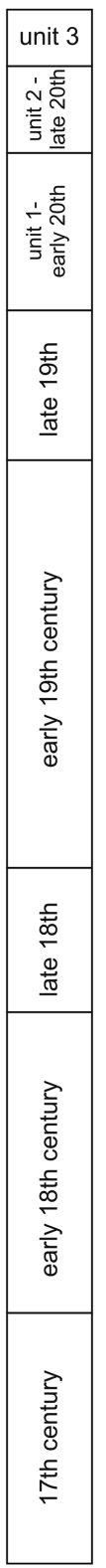

FML
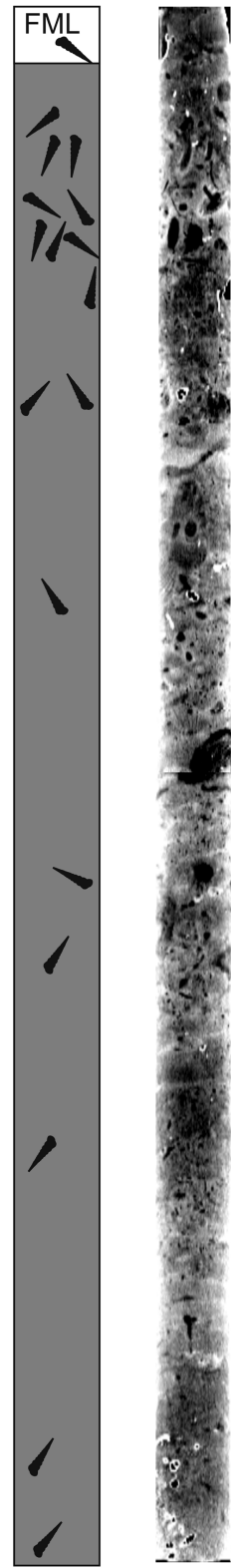

shells

FIGURE 5. Sedimentary fabric of two cores at the Po prodelta and a core at the Isonzo prodelta in radiographs, with subdivision into units, and further subdivision of Po cores into subunits. In X-ray images, light-gray shading represents high sediment bulk density and dark-gray shading represents low sediment bulk density. In the figure, the shading is inverted so that dark shading represents high sediment bulk density: the darkest layers correspond to flood layers; dark-gray shading corresponds to dense, pervasively bioturbated lower parts of the cores (unit 1); and light-gray shading corresponds to weakly bioturbated sediments of unit 2 . The uppermost unshaded parts correspond to the fully mixed layer (FML). The topmost white layers represent the 16- and 6-cm-thick surface FMLs based on ${ }^{210} \mathrm{~Pb}$ profiles. 


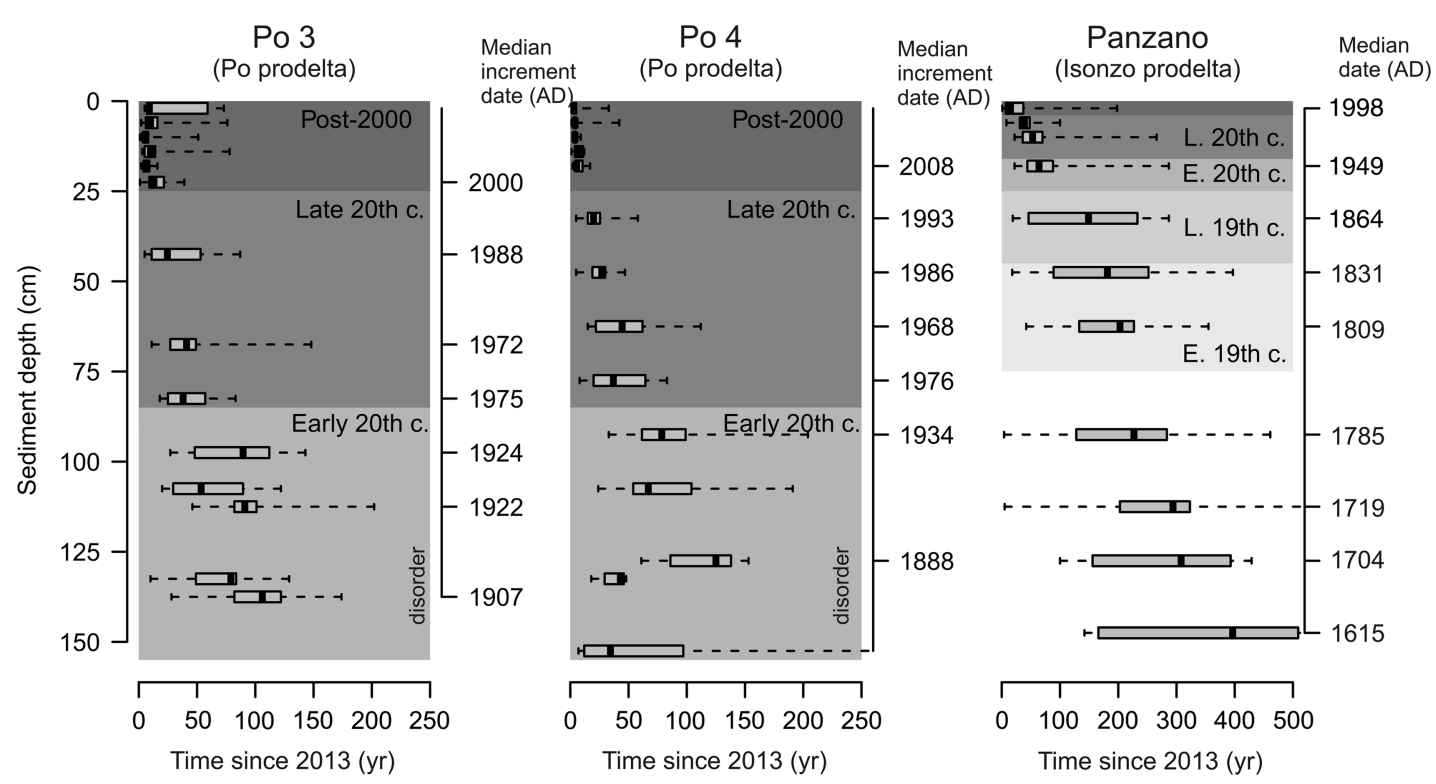

FIGURE 6. Down-core changes in median age of increments and temporal resolution at Po and Panzano. The scale along the y-axis on the right side refers to date (A.D.) of increments on the basis of shell age. The cores at Po 3 and Po 4 are subdivided into three units (post-2000, late twentieth century, and early twentieth century). The lowermost unit shows signs of stratigraphic disorder. These three units (from light to dark gray) are thinner at Panzano. Even when median date at Panzano is A.D.1864 at $30-35 \mathrm{~cm}$ sediment depth, interquartile range of Corbula gibba ages extends into the twentieth century, i.e., a large portion of shells preserved up to $35 \mathrm{~cm}$ lived in the twentieth century.

underlying increments within the three subunits. In contrast, median ages tend to be outside age quartiles of AFDs belonging to different subunits. A major break in median shell age that occurs at $85 \mathrm{~cm}$ coincides with the boundary between units 1 and 2 in both cores. This boundary abruptly separates highly dense sediments with pervasive bioturbation (unit 1) from weakly dense sediments with discrete traces and relicts of stratification (unit 2). The upper and lower age quartiles of assemblages in increments above and below this boundary (upper quartile at $82.5 \mathrm{~cm}$ is A.D. 1955 and lower quartile at 97.5 is A.D. 1964 at Po 3; and upper quartile at $77.5 \mathrm{~cm}$ is A.D. 1948 and lower quartile at 92.5 is A.D. 1951 at Po 4; Fig. 6) indicate that this depositional change occurred in ca. A.D. 1950. The upper $20 \mathrm{~cm}$ at Po 3 and Po 4 are characterized by uniform median shell ages (unit 3), with shells mostly younger than A.D. 2000 (FML). However, several shells older than A.D. 1950 occur in the uppermost $4 \mathrm{~cm}$ increment at Po 3, indicating that they were reworked upward by $>85 \mathrm{~cm}$.

Median shell ages between 100 and $150 \mathrm{~cm}$ in both cores show disorder in terms of nonmonotonic changes in median age of $C$. gibba, with oldest dates reaching to ca. A.D. 1910 at Po 3 and ca. A.D. 1890 at Po 4. Stratigraphic disorder is further documented by the presence of shells of organisms that died after A.D. 2000 at 127.5 and $152.5 \mathrm{~cm}$ at Po 4 (Fig. 6). Median age of these lowermost increments at Po 4 is younger than A.D. 1970, demonstrating downward reworking from unit 3 to unit 1 by more than $100 \mathrm{~cm}$, strongly exceeding the depth of the FML. These increments in unit 1 are characterized by low abundance of $C$. gibba (fewer than 10 individuals per increment).

At Panzano, median shell age declines monotonically from A.D. 1998 at $2-4 \mathrm{~cm}$ to A.D. 1959 at $10 \mathrm{~cm}$, to A.D. 1949 at $18-20 \mathrm{~cm}$, and to A.D. 1864 at $30-35 \mathrm{~cm}$ (Fig. 6). Although the median age of the $30-35 \mathrm{~cm}$ increment falls in the nineteenth century, its upper age quartile reaches to A.D. 1966. Therefore, many shells of organisms that lived in the twentieth century are still preserved in this increment. The upper and lower age quartiles of AFDs within the middle (between 25 and $75 \mathrm{~cm}$ ) and lower parts of the core (between 90 and $150 \mathrm{~cm}$ ) overlap and indicate some degree of mixing across 
$\sim 50 \mathrm{~cm}$. Although down-core changes in median ages do not show stratigraphic disorder, five shells older than 150 years occur in the upper $10 \mathrm{~cm}$. These shells were probably reworked upward to the FML from sediment depths exceeding $30 \mathrm{~cm}$.

Down-Core Changes in ${ }^{210} \mathrm{~Pb}$.- - Down-core profiles in the ${ }^{210} \mathrm{~Pb}$ excess show very irregular profiles at both Po stations (Fig. 7). They can be separated into three phases that coincide with the three units detected by radiographs. First, background values appear below $90 \mathrm{~cm}$, that is, in unit 1 . Second, an overall decline in the ${ }^{210} \mathrm{~Pb}$ excess occurs between $16 \mathrm{~cm}$ and $80-90 \mathrm{~cm}$. Sedimentation rate based on this portion is $2.6 \mathrm{~cm} / \mathrm{yr}(95 \%$ confidence interval $[\mathrm{CI}]=1.2-$ $11.3 \mathrm{~cm} / \mathrm{yr})$ at Po 3 and $2.2 \mathrm{~cm} / \mathrm{yr}(95 \%$ $\mathrm{CI}=1.2-5.6 \mathrm{~cm} / \mathrm{yr}$ ) at Po 4. Third, the uppermost $\sim 16 \mathrm{~cm}$ shows inverted or uniform down-core profiles in the ${ }^{210} \mathrm{~Pb}$ excess (FML), with the lowest values at $16 \mathrm{~cm}$ at both stations. At Panzano, background values occur at 30$40 \mathrm{~cm}$, a relatively regular monotonic decline occurs between $6-30 \mathrm{~cm}$, and excess ${ }^{210} \mathrm{~Pb}$ is uniform in the upper $6 \mathrm{~cm}$ (FML) (Fig. 7). Sedimentation rate based on $0-30 \mathrm{~cm}$ at
Po 3

(Po prodelta)
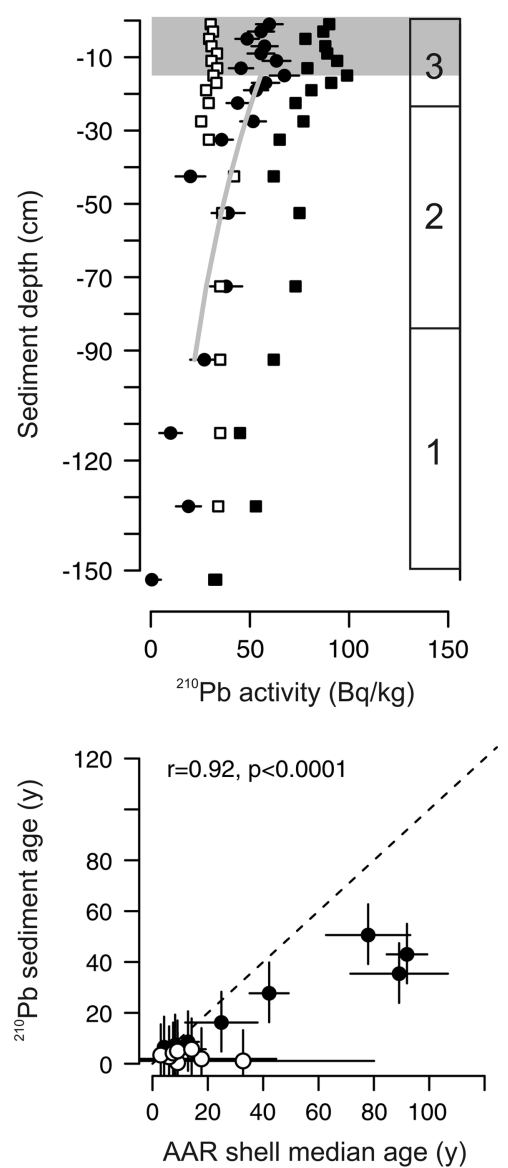

Po 4

(Po prodelta)
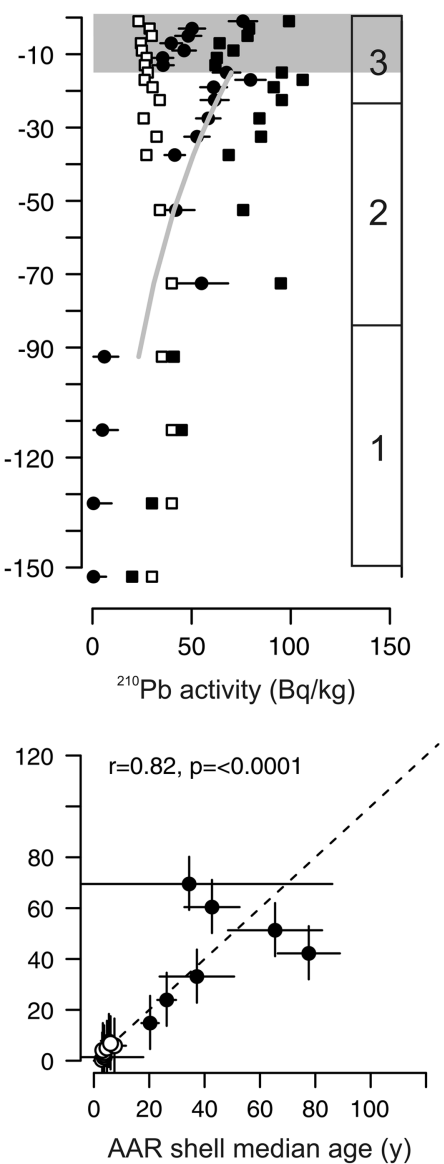

Panzano (Isonzo prodelta)

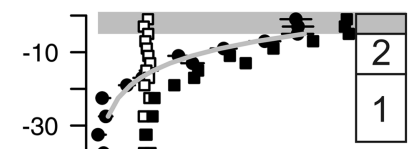

- Supported

- Excess
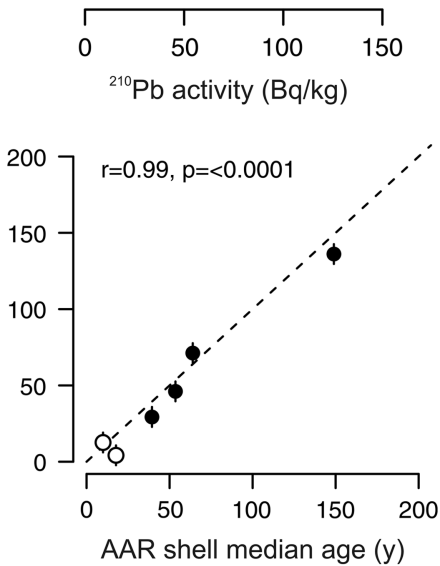

FIgURE 7. Top row: Excess ${ }^{210} \mathrm{~Pb}$ profiles show irregularly uniform values (Po 3) or inverted trends (Po 4$)$ in the upper $16 \mathrm{~cm}$. At Panzano, the upper $6 \mathrm{~cm}$ shows uniform excess ${ }^{210} \mathrm{~Pb}$ values. The upper shaded intervals correspond to the fully mixed layers (FMLs). Sediment dates on the right sides of profiles are based on the constant flux-constant sedimentation model (gray line). The three phases on the right of each core correspond to units distinguished on the basis of X-radiographs and down-core changes in Corbula gibba shell age. Bottom row: Relationship between ${ }^{210} \mathrm{~Pb}$ and AAR median age at Po 3, Po 4, and Panzano, with Pearson correlations. White circles represent the FML, and black circles represent increments below it. 
Panzano is 10 times lower than at Po $(0.24 \mathrm{~cm} /$ $\mathrm{yr}, 95 \% \mathrm{CI}=0.2-0.29 \mathrm{~cm} / \mathrm{yr})$.

Net Sedimentation Rate.-The FML corresponds to the top $16-20 \mathrm{~cm}$ at the two Po stations according to radiographs, homogeneous C. gibba median ages, and irregular excess ${ }^{210} \mathrm{~Pb}$ values. In contrast, the FML at Panzano is just $6 \mathrm{~cm}$ thick based on uniform ${ }^{210} \mathrm{~Pb}$ values and on the basis of the increase of $C$. gibba median ages just below $6 \mathrm{~cm}$. The estimates of sedimentation rates based on down-core changes in median shell ages over the comparable core portions (unit 2) are similar to the estimates based on ${ }^{210} \mathrm{~Pb}$ $(2.1 \mathrm{~cm} / \mathrm{yr}$ at $\mathrm{Po} 3$ under median age $=38 \mathrm{yr}$ at $80-85 \mathrm{~cm}, 2 \mathrm{~cm} / \mathrm{yr}$ at Po 4 under median age $=37 \mathrm{yr}$ at $75-80 \mathrm{~cm}$, and $0.2 \mathrm{~cm} / \mathrm{yr}$ under median age $=149 \mathrm{yr}$ at $30-35 \mathrm{~cm}$ at Panzano). Although the estimates based on ${ }^{210} \mathrm{~Pb}$ can be biased upward by bioturbation (Meysman et al. 2010), ${ }^{210} \mathrm{~Pb}$ sediment ages thus correlate positively with $C$. gibba median ages at all stations $(r>0.8, p<0.001$, at all stations). However, deeper increments show a considerable scatter around the expected oneto-one relationship (Fig. 7). Estimating whether the same sedimentation rate applies to unit 1 at Po 4 is prohibited by stratigraphic disorder. At Po 3, the difference in median age between the upper- and lowermost increments of unit 1 (at 97.5 and $137.5 \mathrm{~cm}$, respectively) is 17 years. The early twentieth-century sedimentation rate is thus $\sim 2.4 \mathrm{~cm} / \mathrm{yr}$, comparable to that of the late twentieth century.

Fitting the AFD from the FML at Po 3 and Po 4 to a one-phase exponential model results in loss rates $\lambda=0.07$ and 0.14 , corresponding to a mean time of shell loss from the 16- to $20-\mathrm{cm}$ thick surface FML equal to 14 and 7 years, and a shell burial rate equal to 1.5 and $2.9 \mathrm{~cm} / \mathrm{yr}$, respectively. These values are comparable to sedimentation rates based on ${ }^{210} \mathrm{~Pb}$ profiles and profiles in shell median age. At Panzano, fitting the AFD from the FML to a one-phase exponential model results in a loss rate of $\lambda=0.035$, that is, the mean time to shell loss from the 6cm-thick FML is 29 years. Therefore, a shell burial rate equal to $0.21 \mathrm{~cm} / \mathrm{yr}$ is similar to sedimentation rates based on ${ }^{210} \mathrm{~Pb}$ and median shell age. To conclude, the steepness of AFDs in the FML is primarily determined by burial rather than by disintegration at all stations.

Down-Core Changes in Time Averaging and Disorder.-At the scale of three stratigraphic units in each core, the AFDs show a downcore shift from right-skewed distributions in unit 3 (coinciding with the FML) to unimodal, more symmetric distributions in units 1 and 2, with decreasing temporal resolution (Fig. 8). IQR (corrected for calibration age error) of stratigraphic increments increases from 2-3 years in unit 3 , to $\sim 14-23$ years in unit 2 , and to $27-29$ years in unit 1 at the Po stations, and from 9-20 years in units 2 and 3 to 75 years in unit 1 at Panzano (Fig. 8).

At $\mathrm{Po}$, annual to decadal time averaging of 4to 5-cm-thick increments in unit 3 (earliest twenty-first century, median $\mathrm{IQR}=1-3 \mathrm{yr}$ ) and in unit 2 (late twentieth century, median IQR = $14-15 \mathrm{yr}$ ) is smaller by a factor of two relative to multidecadal to centennial time averaging in unit 1 (early twentieth century, median IQR = 25-28 yr; Fig. 9A). The difference in time averaging between units 2 and 3 on one hand and unit 1 on the other holds when postdepositional cohorts are removed (Fig. 9B). Similarly, as at $\mathrm{Po}$, time averaging of 4 - to 5 -cm-thick increments at Panzano deposited during the late twentieth century (median IQR $=12 \mathrm{yr}$ ) is lower than in sediments during the early twentieth century (median IQR $=67 \mathrm{yr}$ ).

Stratigraphic disorder at the scale of 4- to 5$\mathrm{cm}$-thick increments increases down core at all stations (Fig. 9C). The correlation between individual ages and their sediment depth shows a significant stratigraphic order in the late twentieth century (Spearman $r=0.24$, $p=0.03$ at Po 3, and $r=0.34, p<0.001$ at Po 4) and a lack of order in the early twentieth century at both stations (Spearman $r=0.1, p=0.43$ at Po 3, and $r=-0.04, p=0.79$ at Po 4). Unit 3 (earliest twenty-first century) shows a significant order at Po $4(r=0.27, p=0.04)$ but not at Po 3 ( $r=-0.1, p=0.37)$. However, this unit is much thinner than unit 2 , being effectively equivalent to the FML. Stratigraphic order is preserved in both units at Panzano $(r=0.41$, $p=0.007$ in the early twentieth century, and $r=0.53, p<0.0001$ in the late twentieth century). 

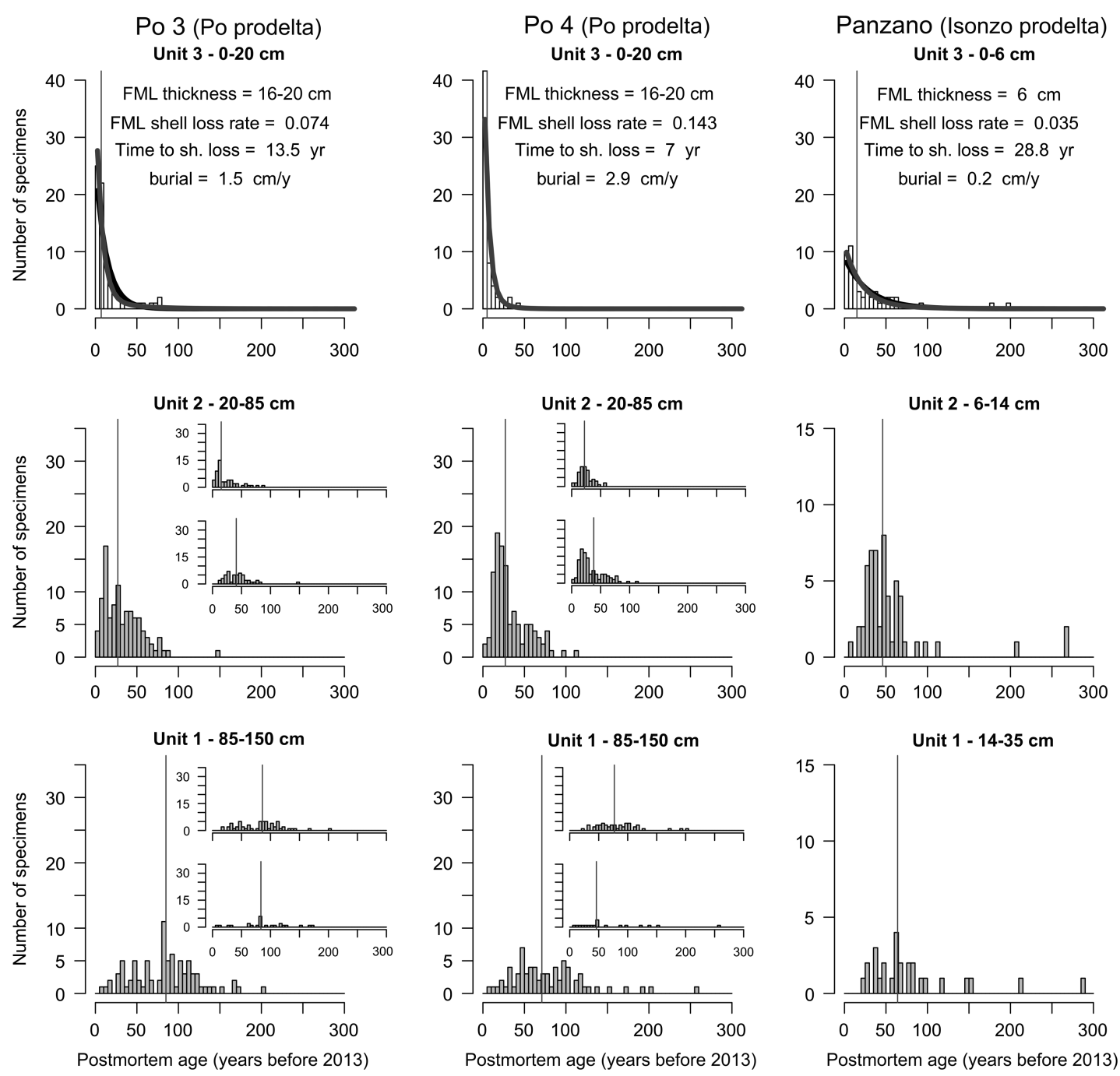

FIGURE 8. Down-core changes in age-frequency distributions (AFDs) in three stratigraphic units containing shells of Corbula gibba that lived mainly in the twentieth century; median age and resolution decrease down core and skewness becomes smaller. The upper row shows AFDs from the uppermost sediment increments corresponding to the fully mixed layer (FML), with the lines fitted by the simple exponential model and corresponding estimates of shell loss rate from this layer and estimates of shell burial (assuming that disintegration in the FML is minor relative to loss caused by burial). AFDs of subunits 1 and 2 have similar shapes within unit 1 and AFDs of subunits 3 and 4 have similar shapes within unit 2. Subsurface assemblages are characterized by unimodal, symmetric AFDs. Vertical line represents median age.

Stratigraphic Patterns in Abundance of Corbula gibba and in the Composition of Communities.Absolute and proportional abundances show similar trajectories at both Po stations. Absolute abundances are low in the lowest unit, increase sharply to 50-75 individuals at $85 \mathrm{~cm}$ at $\mathrm{Po} 3$ and to $\sim 100$ individuals at $80 \mathrm{~cm}$ at $\mathrm{Po} 4$, remain high in unit 2 , and decline to low values in unit 3 (Fig. 10). Proportional abundances at Po 3 and Po 4 show similar trends, achieving $20-30 \%$ in unit $1,50-60 \%$ in unit 2, and $20-40 \%$ in unit 3. At Panzano, C. gibba increases from 50 individuals at $25 \mathrm{~cm}$ to 100 individuals at $16-20 \mathrm{~cm}$, and from $25 \mathrm{~cm}$ $(10 \%)$ upward to $\sim 20 \%$ at $12 \mathrm{~cm}$. Changing the vertical sediment-depth scale to a temporal axis represented by median ages, the maxima in absolute and proportional abundances occur 

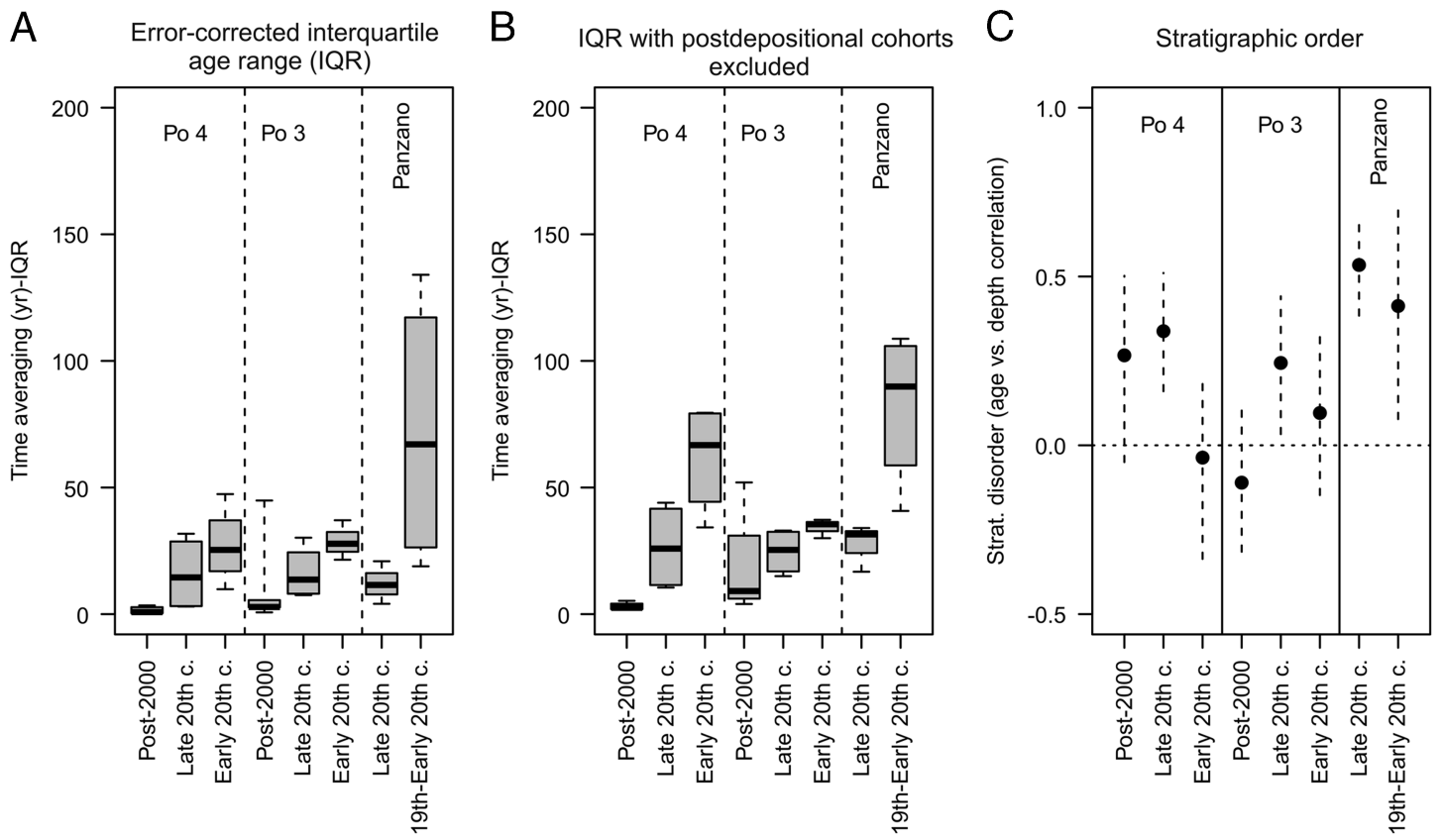

FIGURE 9. Down-core decline in temporal resolution and stratigraphic order (per 5-cm-thick increments) characterize all stations: A, Changes in interquartile age range corrected for calibration error; B, changes in interquartile age range, excluding postdepositional age cohorts; C, changes in stratigraphic order (Spearman's rank correlation). Stratigraphic disorder and temporal resolution is not shown for unit 3 at Panzano, because it is represented by one increment only.

in the latest part of the twentieth century in both regions. These trends in C. gibba dominance are associated with significant changes in the composition of molluscan communities in both regions between the early and late twentieth century at Po 3 (PERMANOVA, $F=7.3, \quad p<0.001)$, Po 4 $(F=6.9, \quad p<0.001)$, and Panzano $(F=4.6$, $p<0.001)$, mainly marked by the decline in evenness and by the decline in abundance of the formerly frequent gastropods (Turritella communis) and bivalves (Kurtiella bidentata) (Fig. 11).

Sediment grain size does not show any fining-upward trend, but concentrations of TOC (from $~ 1 \%$ to $1.5-1.7 \%$ ) and TN (from $\sim 0.05 \%$ to $0.15 \%$ ) increase up-section in sediments of the twentieth century at all stations. They rise abruptly at $80-90 \mathrm{~cm}$ at both Po stations and at $20 \mathrm{~cm}$ at Panzano, that is, between units 1 and 2 in both regions (Fig. 10). TOC concentrations peak in unit 2 rather than in unit 3 at the Po stations. TOC concentrations correlate positively with absolute abundances of C. gibba at Po and Panzano and have significantly positive effects in generalized least-square models at the Po stations (Table 1). At Panzano, proportional abundances also correlate positively with concentrations of TOC, but less strongly (Table 1).

Unmixed Patterns in Abundance of Corbula gibba.-Unmixing cohort abundance shows that standing density of C. gibba monotonically increased during the twentieth century at both Po stations (Fig. 12). The increase is less abrupt than observed on the basis of stratigraphic patterns. Absolute abundances increased steadily up to A.D. 2000 at Po 3, up to the 1980s at Po 4, and up to the mid-1970s at Panzano (Fig. 12). These trajectories are comparable to historical survey data that show an increase in standing density of $C$. gibba between the early and late twentieth century, a peak in standing density in the 1970s to 1990s in the NW Adriatic and in the 1990s in the Gulf of Trieste (white box plots in Fig. 12). The survey data indicate that median density declined after the 2000s. However, densities reaching up to 4000 individuals $/ \mathrm{m}^{2}$ in the 

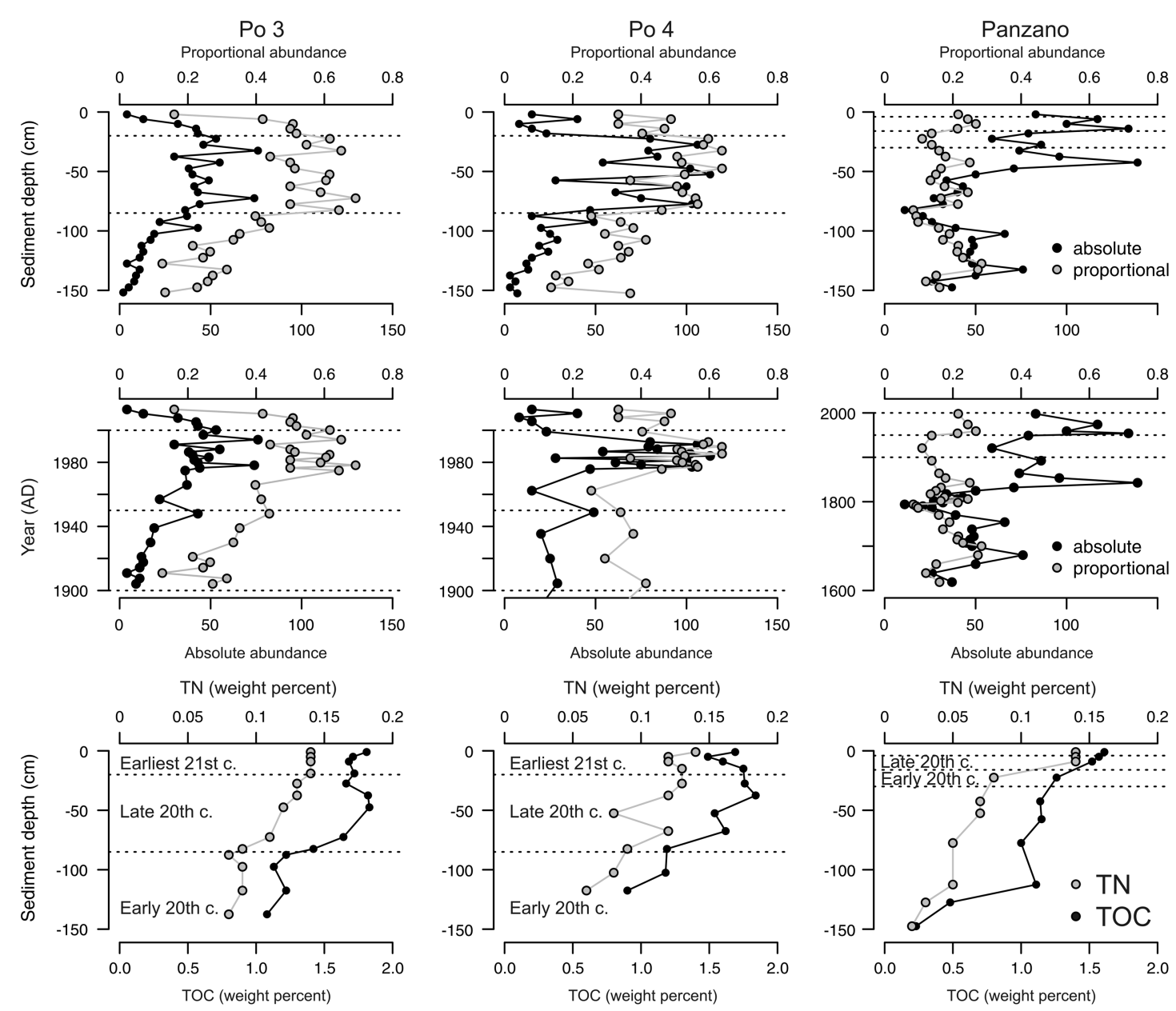

FIGURE 10. Top and middle rows: Absolute and proportional abundances (relative to all mollusks) of Corbula gibba scaled against sediment depth (top row) and against time (middle row) show that both sharply increased at $85 \mathrm{~cm}$, i.e., at median time equal to $1970 \mathrm{~s}$, at Po3 and Po 4, and at $16 \mathrm{~cm}$, i.e., at median time equal to 1950s, at Panzano. Bottom row: A general down-core decrease in concentrations of total organic carbon (TOC) and total nitrogen (TN) at all stations. However, TOC tends to show the highest values in unit 2 at both Po stations, coinciding with the reduced bioturbation and high abundance of $C$. gibba.

NW Adriatic and up to 700 individuals $/ \mathrm{m}^{2}$ in the Gulf of Trieste were observed in the 2010s (Fig. 12). Depending on average perindividual life span, the core-based estimates of standing density attained in the late twentieth century varied between 1000 individuals $/ \mathrm{m}^{2}$ (life span $=2 \mathrm{yr}$ ) to 20003000 individuals $/ \mathrm{m}^{2}$ (5 yr) at the Po stations, and between 500 individuals $/ \mathrm{m}^{2}(2 \mathrm{yr})$ to 1500 individuals $/ \mathrm{m}^{2}$ (5 yr) at Panzano. The estimates of standing density in historical surveys are comparable to core-based estimates that assume an average life span of about 2 years.
At 10-year resolution, unmixed abundances of $C$. gibba correlate negatively with the median of minimum monthly concentrations of dissolved oxygen at Po and at Panzano (Fig. 12, Table 1). The effect of dissolved oxygen on unmixed abundances is also significantly negative (Table 1). The rank correlation with temperature is moderately positive at $\mathrm{Po}$ (Spearman $r$ [Po 3] $=0.6, p=0.056 ; r$ [Po $4]=0.59, p=0.06$ ) and negligible at Panzano, where the decline in abundance between 1980 and 2000 is not in phase with increasing temperature $\quad(r \quad[$ Panzano] $=-0.14, \quad p=0.67)$. Although the frequency of floods of the Po and 

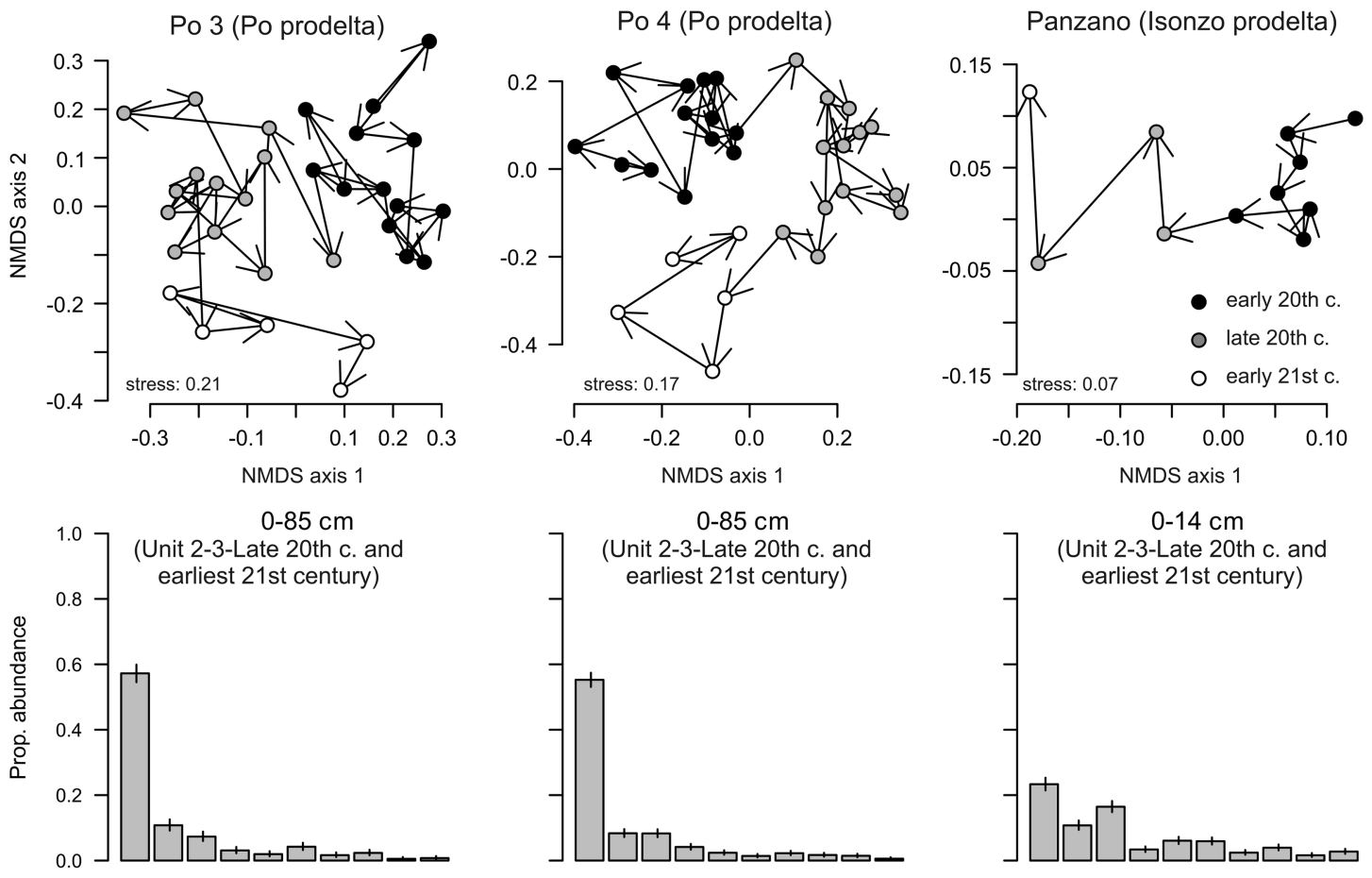

$0-85 \mathrm{~cm}$

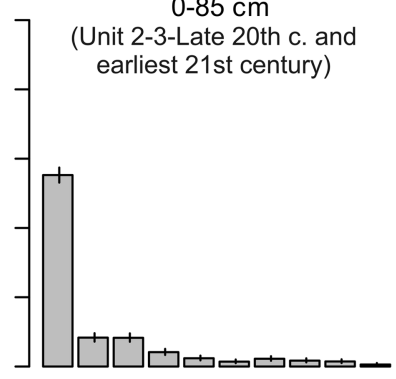

$0-14 \mathrm{~cm}$

(Unit 2-3-Late 20th c. and earliest 21st century)

$85-155 \mathrm{~cm}$
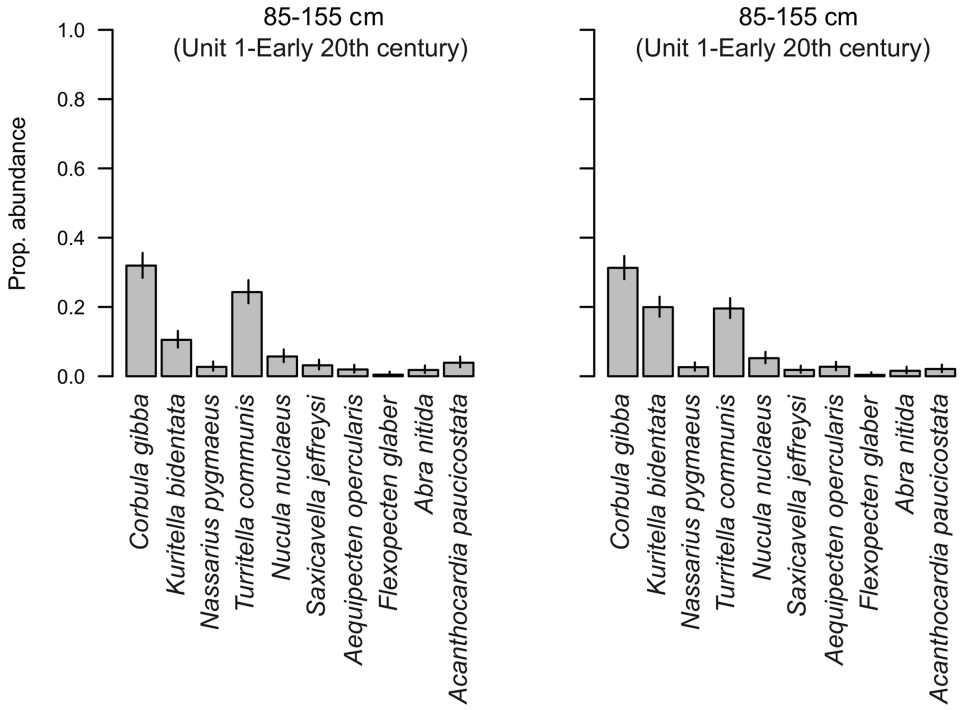

$14-35 \mathrm{~cm}$ (Unit 1-Early 20th century)
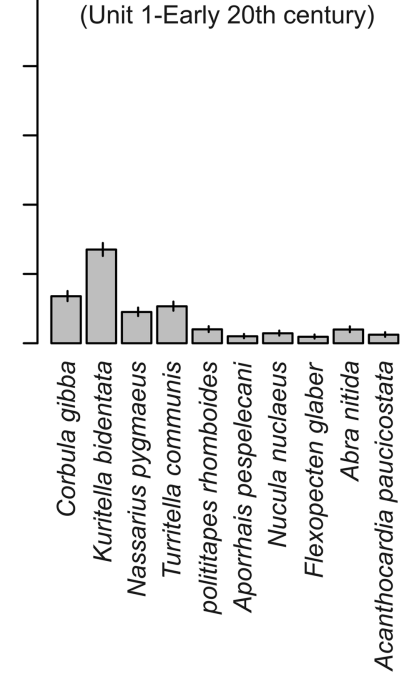

FIGURE 11. Changes in the molluscan community composition at Po and at Panzano during the twentieth century. Top row: Nonmetric multidimensional scaling shows that assemblages from the early and late twentieth century differ in square-root-transformed proportional species abundances. Corbula gibba was excluded from these analyses. Arrows are drawn from older to younger assemblages. Middle and bottom rows: Bar plots based on pooled abundances in unit 1 and units 2-3 showing the increase in proportional abundance of $C$. gibba and the decrease of Turritella communis and Kurtiella bidentata at all stations.

Isonzo Rivers slightly increased during the twentieth century (Zanchettin et al. 2008; Siche and Arnaud-Fassetta 2014), per-decadal maximum daily discharge of the Po and Isonzo Rivers does not correlate with unmixed abundances of C. gibba (Spearman $r$ [Po 3] $=-0.34$, 
TABLE 1. Rank correlations, partial rank correlations, and generalized least-square (GLS) slope estimates of the effects of total organic carbon (TOC) and dissolved oxygen concentrations on raw and unmixed abundance of Corbula gibba in sediments that were largely deposited during the twentieth century.

\begin{tabular}{|c|c|c|c|c|c|c|}
\hline & $\begin{array}{c}\text { Spearman } \\
r\end{array}$ & $p$ & $\begin{array}{c}\text { Partial } \\
\text { Spearman } r\end{array}$ & $p$ & $\begin{array}{l}\text { GLS } \\
\text { slope }\end{array}$ & $p$ \\
\hline \multicolumn{7}{|c|}{$\begin{array}{l}\text { Corbula gibba absolute abundance (in } 4-5 \mathrm{~cm} \text { strati- } \\
\text { graphic increments) } \sim \text { TOC }\end{array}$} \\
\hline Po 3 (Po prodelta) & 0.5 & 0.011 & 0.58 & $<0.001$ & 30.5 & 0.048 \\
\hline Po 4 (Po prodelta) & 0.52 & 0.004 & 0.44 & 0.01 & 70.9 & 0.022 \\
\hline Panzano (Isonzo prodelta) & 0.67 & $<0.001$ & 0.4 & 0.022 & 36.3 & 0.14 \\
\hline \multicolumn{7}{|c|}{$\begin{array}{l}\text { Corbula gibba proportional abundance (in } 4-5 \mathrm{~cm} \text { strati- } \\
\text { graphic increments) TOC }\end{array}$} \\
\hline Po 3 (Po prodelta) & 0.5 & 0.01 & 0.44 & 0.021 & 0.14 & 0.3 \\
\hline Po 4 (Po prodelta) & 0.61 & 0.0004 & 0.39 & 0.032 & 0.33 & 0.0004 \\
\hline Panzano (Isonzo prodelta) & 0.05 & 0.8 & 0.07 & 0.7 & 0.007 & 0.88 \\
\hline \multicolumn{7}{|c|}{$\begin{array}{l}\text { Corbula gibba standing abundance (unmixed) } \\
\sim \text { Dissolved oxygen }(\mathrm{ml} / \mathrm{L})\end{array}$} \\
\hline Po 3 (Po prodelta) & -0.86 & $<0.001$ & -0.46 & 0.14 & -133 & $<0.001$ \\
\hline Po 4 (Po prodelta) & -0.93 & $<0.001$ & -0.86 & $<0.001$ & -75 & 0.008 \\
\hline Panzano (Isonzo prodelta) & -0.56 & 0.07 & -0.79 & 0.0002 & -63 & 0.03 \\
\hline
\end{tabular}

$p=0.28 ; r[\mathrm{Po} 4]=-0.1, p=0.777 ; r$ [Panzano $]=-0.4, p=0.33)$.

\section{Discussion}

Preservation of Flood Stratification at the Po Prodelta.-The delta front and prodelta of the Po River are flood dominated, with sedimentation driven by flocculation from hypopycnal river plumes and gravity-driven sediment transport (Traykovski et al. 2007), especially under very high river discharge. Seven major floods with daily peak discharges above $8000 \mathrm{~m}^{3} / \mathrm{s}$ occurred in the twentieth century (Zanchettin et al. 2008), in 1917, 1926, 1928, 1951, 1976, 1994, and 2000, with the absolute maximum discharge observed on 20 May 1926. These flood events at the Po prodelta tend to be recognized by dense (bright) and laminated layers in radiographs (Wheatcroft et al. 2006; Tesi et al. 2012), comparable to relictual layers at the Po stations observed here (Fig. 13). Another flood occurred in 2009 but did not leave distinct layers of laminated deposits at the deeper prodelta (Tesi et al. 2011). The low excess ${ }^{210} \mathrm{~Pb}$ activity at $16 \mathrm{~cm}$, coinciding with the upper bright layer in radiographs at $16-20 \mathrm{~cm}$ at Po 3, also suggests that the layers at the two Po stations reflect flood events, because flood deposits of the Po prodelta have low ${ }^{210} \mathrm{~Pb}$ concentrations due to a short time for absorption (Palinkas and Nittrouer 2007). IQRs of shells in 4-cm-thick increments in unit 3 at both stations are mostly less than 13 years, and the median date of C. gibba immediately underlying unit 3 at $20 \mathrm{~cm}$ is A.D. 2000 . Therefore, unit 3 formed after A.D. 2000, and the dark layer at $16-20 \mathrm{~cm}$ at $P o 3$ corresponds to a 100-year flood in the autumn of 2000 (Wheatcroft et al. 2006; Miserocchi et al. 2007; Tesi et al. 2012). The ages of shell in layers at 80 , 50 , and $35 \mathrm{~cm}$ at $P o 3$ and 85,50 , and $30 \mathrm{~cm}$ at Po 4 coincide with major floods in 1951, 1974, and 1994, respectively (Fig. 13). Therefore, bright relictual layers in cores at Po probably represent flood events. No flood layers can be detected at Panzano. In the section on Temporal Changes in Bioturbation, we argue that the preservation of flood layers in sediments deposited in the late twentieth century at Po is related to a major midcentury decline in the depth and frequency of bioturbation.

Spatial Changes in Time Averaging.-On one hand, estimates of the late twentieth-century sedimentation rates at Po $(\sim 2 \mathrm{~cm} / \mathrm{yr})$ are 10 fold higher than at Panzano $(\sim 0.2 \mathrm{~cm} / \mathrm{yr})$. On the other hand, the effects of bioturbation are stronger at Po than at Panzano: (1) FML is thicker by factor of $\sim 2.5$ at the Po prodelta and (2) substantial downward and upward reworking of very young and very old shells indicates that incomplete mixing reaches 

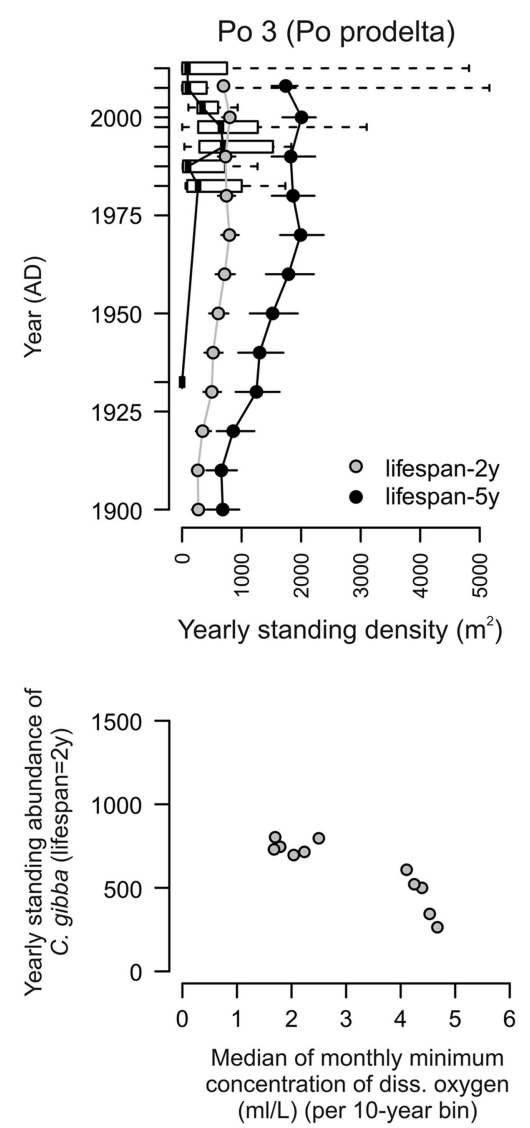

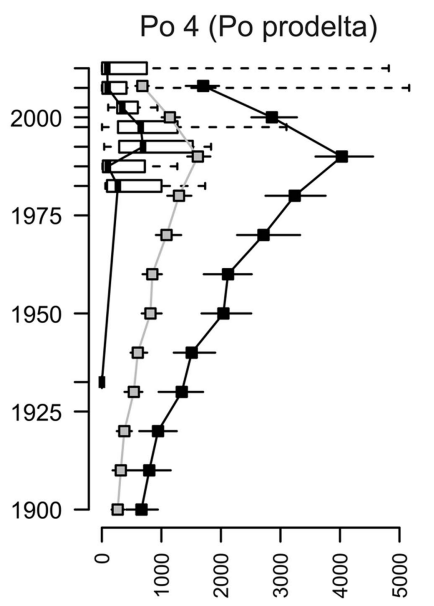

Yearly standing density $\left(\mathrm{m}^{2}\right)$

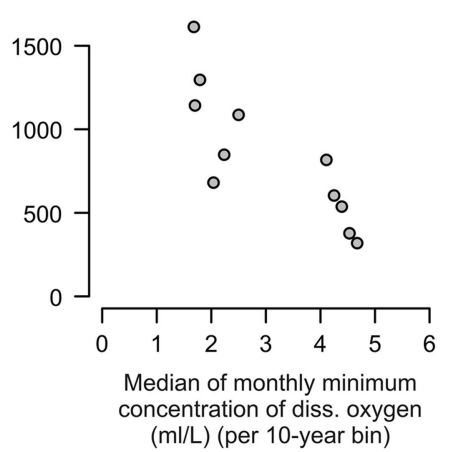

Panzano (Isonzo prodelta)

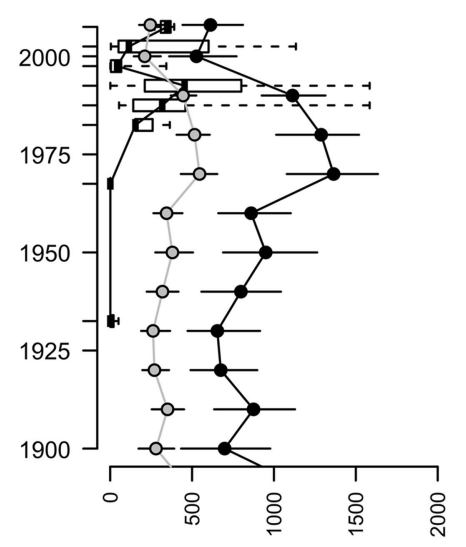

Yearly standing density $\left(\mathrm{m}^{2}\right)$

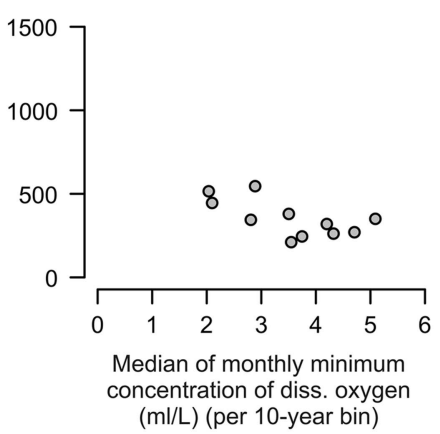

FIGURE 12. Top row: White box plots show temporal changes in standing density of Corbula gibba (individuals $/ \mathrm{m}^{2}$ ) based on published historical surveys (5-30 m water depth) during the twentieth century in the NW and NE Adriatic at 5-year resolution. The 1934-1935 data are from Vatova (1949). Gray and black lines show changes in density predicted by cohort abundance (accounting for abundances in all increments and interpolating shape of age-frequency distributions), assuming life span of 2 and 5 years, respectively. The reversal in density at the top, observed both in living communities and in core assemblages, likely reflects the most recent oligotrophization. Bottom row: Reconstructed changes in standing density of C. gibba at Po and Panzano are significantly negatively related to the bottom-water concentrations of dissolved oxygen (DO), computed as median of minimum monthly concentrations in 10-year bins.

$100 \mathrm{~cm}$ below the FML at the Po prodelta. Shrimps also burrow to $90 \mathrm{~cm}$ in sediments of the Isonzo prodelta (Pervesler and Hohenegger 2006), but the abundance of such burrows is probably less than in the Po prodelta. The 10fold difference in sedimentation rates is thus partly compensated by higher mixing at Po, generating a transit time of shells below the FML (Wheatcroft 1990) that is four times shorter at Po than at Panzano. One of the major correlates of the bioturbation intensity in other marine environments is the availability of labile organic matter (Boudreau 1994; Smith and Rabouille 2002) that tends to positively correlate with sedimentation rate. Therefore, higher primary productivity at the Po prodelta compared with the Isonzo prodelta can explain the positive covariation between the depth of bioturbation and sedimentation rate (and concentrations of TOC in sediment) observed here.

Down-Core Changes in Time Averaging.Time averaging observed in a given stratigraphic increment can be compared against time averaging that would be expected under constant rate of burial of shells below the FML. In this case, burial times are exponentially distributed, and the IQR of shell ages in the FML is expected to be equal to $\log (3)$ divided by inverse of time to burial of shells to the underlying layer. 


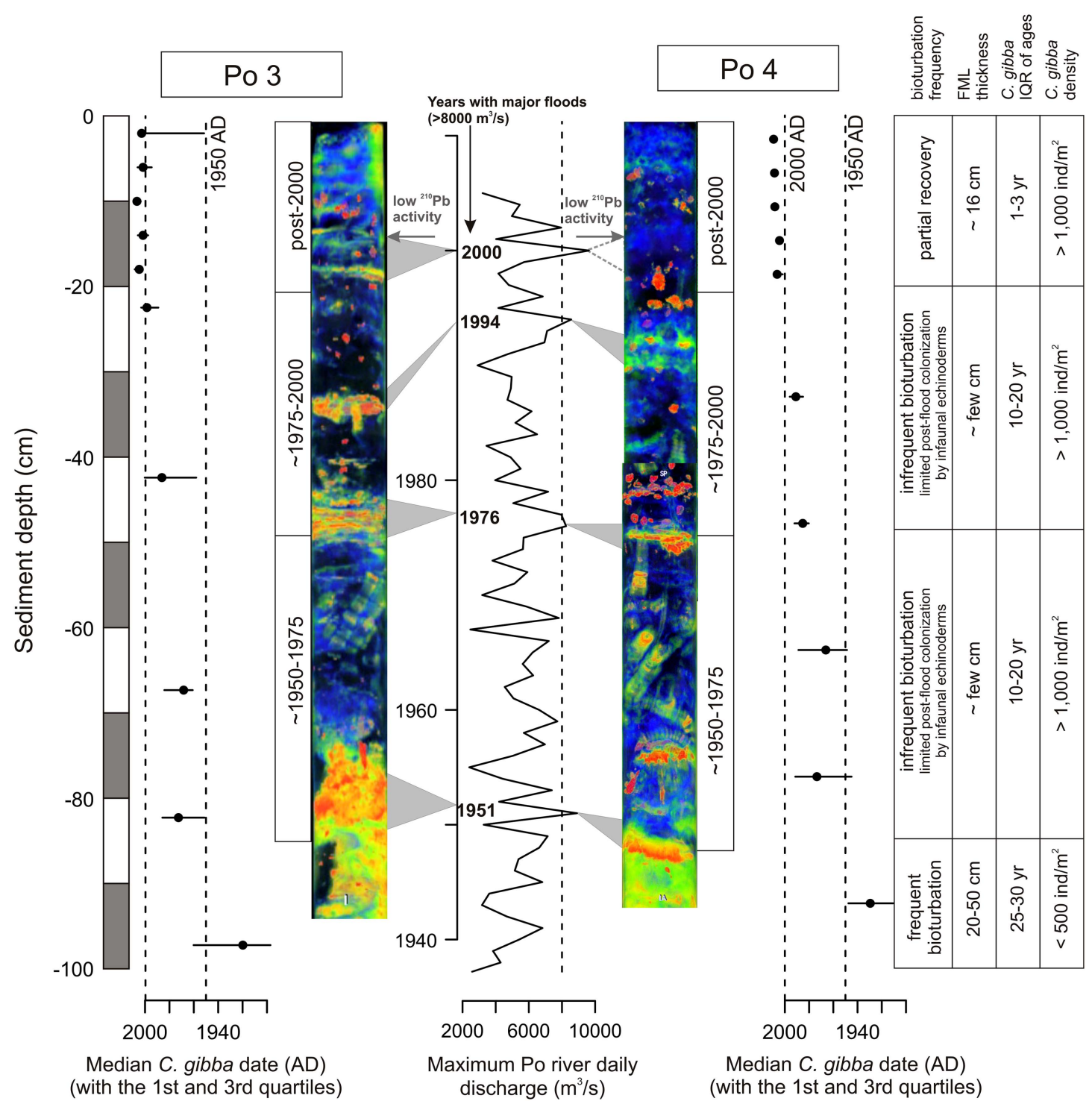

FIGURE 13. The replacement of pervasively bioturbated sediments with high bulk density, decadal time averaging (IQR), and low abundance of Corbula gibba (early twentieth century) by organic-rich sediments with low bulk density, discrete echinoderm traces, relictual flood layers, yearly time averaging, and high abundance of $C$. gibba (late twentieth century) documents a major regime shift in ecosystem functioning driven by higher frequency of hypoxia in the late twentieth century. Flood layers at the Po prodelta are preserved in the late twentieth-century portion of sediment cores when the depth and rate of bioturbational mixing were reduced. The stratigraphic positions of bright (orange-colored in X-rays) relictual layers correspond to the timing of major flood events recorded at the Po prodelta during the twentieth century (according to Zanchettin et al. 2008). FML, fully mixed layer; IQR, interquartile range.

Therefore, using the present-day estimates of FML thickness and sedimentation rate, IQRs of C. gibba assemblages should be $\sim 9$ years at the Po prodelta (i.e., time to burial below the 16$\mathrm{cm}$-thick FML at $2 \mathrm{~cm} / \mathrm{yr}$ is $8 \mathrm{yr}$, and $\log (3) /$ $(1 / 8)$ is $9 \mathrm{yr})$ and $\sim 33$ years at the Isonzo prodelta. IQRs of C. gibba assemblages are comparable to these predictions in units 2 and 3 (i.e., deposited during the late twentieth century and the earliest twenty-first century). However, IQRs in unit 1 are higher by a factor of two or three in both regions (Fig. 9). This difference in time averaging is thus partly generated by incomplete, nonlocal mixing 
below the FML by burrowers in the twentyfirst century that moved some shells younger than 10 years from unit 3 to the lowermost increments in unit 1 (and from unit 1 to unit 3) at both Po stations (Fig. 6).

However, we suggest that this difference is also generated by stronger bioturbation in the early twentieth century, because time averaging of increments in unit 1 remains high even when postdepositional cohorts are excluded (Fig. 9B). The down-core changes in time averaging and stratigraphic disorder are driven by reduced bioturbation rather than by increased sedimentation, because the distribution of shell ages does not indicate any increase in net sedimentation rate toward the top of the cores in both regions. Annual sediment load from the Po delta was higher in the early twentieth century than in the late twentieth century (sandy sediment input to the coastal environments has stopped over the past $50 \mathrm{yr}$ due to dam construction, soil protection, and massive riverbed excavation; Correggiari et al. 2005), late-highstand sedimentation rates at Po ( 0.5-2 cm/yr; Scarponi et al. 2013) are comparable to late twentieth-century sedimentation rates at Po (Palinkas and Nittrouer 2007), and the time required to destroy flood layers a few centimeters thick is just a few years at the Po prodelta (Tesi et al. 2012). At $20 \mathrm{~m}$ water depth in front of southern distributary channels that are close to the stations sampled in our study, the original thickness of the 2000 flood layer is less than $5 \mathrm{~cm}$ (Wheatcroft et al. 2006). Only at the northern prodelta off the most active channel (Po di Pilla; Correggiari et al. 2005) are flood layers $20-25 \mathrm{~cm}$ thick (Orange et al. 2005). Although bases of such layers can remain intact, more than $50 \%$ of a 24 $\mathrm{cm}$-thick flood layer deposited in A.D. 2000 at 13 $\mathrm{m}$ water depth was completely reworked in the course of several years (Tesi et al. 2012).

Due to higher sedimentation/mixing ratio at Po compared with Panzano, the mismatch between raw (mixed) and umixed temporal patterns in abundance of C. gibba, as observed at the scale of the whole core at Panzano (Tomašových et al. 2017), does not strongly affect the cores at Po. In the top interval at Panzano that corresponds to the twentieth century, the trajectory of increasing C. gibba abundance is still preserved in the twentiethcentury sediments, in contrast to the middle and lower part of the cores. Therefore, the decline in bioturbation induced by anthropogenic impacts increased the preservation potential of stratigraphic trends in both regions.

Temporal Changes in Bioturbation and in Abundance of Opportunists between the Early and Late Twentieth Century.-In spite of geographic differences in sedimentation and mixing, qualitatively similar stratigraphic trends in abundance of C. gibba and in temporal resolution occur in circalittoral habitats at the Po and Isonzo prodeltas. Therefore, the depositional changes that affected preservation of flood layers and ichnofabric, compositional changes, and changes in the abundance of a major opportunistic species occurred over broad spatial scales in the northern Adriatic Sea between the early and late twentieth century. Pervasive bioturbation, as observed in the early twentieth-century sediments in our cores, is typical of natural highstand deposits of the Po prodelta (Amorosi et al. 2008, 2016). In the absence of environmental stressors, bioturbation in the northern Adriatic Sea is produced by the shrimps Squilla mantis (Fig. 3A,B), Jaxea nocturna (Pervesler and Dworschak 1985), or Upogebia pusilla (Pervesler and Hohenegger 2006), fishes, polychaetes (Fig. 3C), echinoderms (Schinner 1993), and mollusks (Atkinson and Froglia 2000), and their activities are expected to quickly erase centimeter-scale stratification produced by flood events. Therefore, stratigraphic changes in temporal resolution, in preservation of flood layers, and in preservation of echinoderm traces between units 1 and 2 in both regions, and higher TOC concentrations in unit 2 at the Po stations indicate a major change in ecosystem functioning during the late twentieth century. We suggest that this change reflects a regime shift that was marked by the relatively abrupt midcentury decline in bioturbation rate and depth (Fig. 13). Distinct echinoderm burrows penetrating flood layers in unit 2 at Po show that the sediment was intermittently mixed by subsurface deposit feeders in the late twentieth century. 
However, the preservation of flood layers and the distinctiveness of traces suggest that these mixing events were limited in frequency (e.g., Savrda and Bottjer 1991; Virtasalo et al. 2011) and were insufficient to fully mix surface sediments. Irregular echinoids, most likely Ova canalifera, took advantage of organicmatter enrichment in the wake of flood events, but the colonization window was probably limited by the next hypoxia event. The thickness of the FML probably attained 20$50 \mathrm{~cm}$ in the early twentieth century, in contrast to a few centimeters in the late twentieth century (Fig. 13).

The present-day FML thickness of at least $16 \mathrm{~cm}$ and the signs of deeper incomplete mixing at the Po prodelta (with high density of shrimp mounds on the seafloor) can reflect a renewal in bioturbation in the earliest twentyfirst century. This renewal is suggested by the decline in TOC in sediment cores, probably reflecting the lower frequency of hypoxia directly observed since the 1990s in the northern Adriatic Sea (Djakovac et al. 2015). At Panzano, stratigraphic changes in stratification cannot be detected due to slower sedimentation rate and because flood events do not reach such magnitude as at the Po prodelta.

The decline in bioturbation depth and frequency associated with outbreaks of shallowburrowing opportunistic species can occur under multiple stressors that impede infaunal colonization, including oxygen deficiency (Diaz and Rosenberg 1995; Villnäs et al. 2012; Gogina et al. 2014; Briggs et al. 2015), high sedimentation rates in deltaic environments (MacEachern et al. 2005), or sediment disturbance by trawling and dredging (Thrush and Dayton 2002). Absolute abundances of $C$. gibba were repeatedly high over the past centuries in the northern Adriatic Sea (Tomašových et al. 2017). However, a combination of very limited bioturbation (persisting over years to few decades) with outbreaks of $C$. gibba and reduced abundance of formerly abundant species (leading also to high proportional abundance of $C$. gibba) might represent the unique signature of anthropogenic stress that developed in the late twentieth century. The increase in C. gibba abundance is associated with a major decline in abundance of the suspension-feeding gastropod T. communis. This species was significantly more abundant in unit 3 at both Po stations and at Panzano, that is, in the early twentieth century (Fig. 11). Therefore, this twentieth-century change affected the whole molluscan community composition.

Association between Outbreaks, Limited Bioturbation, and Hypoxia.-Historical data on the concentrations of dissolved oxygen show a major increase in the frequency of hypoxic events in the late twentieth century (Fig. 2C), with regional hypoxic events $(<1 \mathrm{ml} / \mathrm{L})$ occurring in the Gulf of Trieste in 1974, 1983, 1988, 1990, 1994, and 2001 (Faganeli et al. 1985; Stachowitsch 1991; Cibic et al. 2009), and in the NW Adriatic off the Po River delta in 1977, 1982, 1983, 1989-1991, 1994, 1997, and 2004 (Degobbis et al. 1979; Vidakovic and Zavodnik 1984; Rinaldi et al. 1992; Djakovac et al. 2015). The twentieth-century increase in C. gibba abundance based on unmixing and the decline in the depth and frequency of bioturbation strongly coincide with this increase in frequency of hypoxic events in the late twentieth century (Fig. 12, Table 1). The reconstructed trajectory at 10 -year resolution probably reflects a higher frequency of outbreaks occurring over few years, separated by years with low abundance (Hrs-Brenko et al. 1994), rather than a simple continuous increase in standing density.

The increase in the frequency of hypoxia, hypothesized to be at least partly driven by a major increase in fertilizer use (Fig. 2), is in phase with the up-core increase in TOC and TN occurring relatively abruptly just at the transition between the early and late twentieth century observed in our cores (Fig. 10), as is also observed in other cores in the Gulf of Trieste (Ogrinc and Faganeli 2006). The downcore increase in TOC within the mixed layer is expected due to organic-matter remineralization in the sediment and stratigraphic changes in TOC and thus may not simply reflect temporal changes in organic-matter production and preservation (Burdige 2007). However, non-monotonic down-core changes in TOC at Po stations, with the highest values in unit 2, indicate that they do reflect temporal changes in organic-matter preservation. Therefore, we 
suggest that depth and frequency of bioturbation was limited by an increase in the frequency of bottom-water hypoxia (as observed also in other studies: Solan et al. 2008; Virtasalo et al. 2011; Wetzel et al. 2011). Such an increase would (1) directly and indirectly (via suppression of infaunal bioirrigation) limit concentrations of dissolved oxygen in the sediment and thus reduce the remineralization of refractory organic matter (Aller 1994; Kristensen 2000; Burdige 2007), (2) lead to local extirpation and delayed recovery of hypoxia-sensitive species such as T. communis, and (3) enable outbreaks of $C$. gibba in the wake of hypoxic events. This species is tolerant to seasonal oxygen crises, is able to feed on both phytoplankton and organic particles from the sediment surface (Yonge 1946), and probably benefits from the reduction in competition and predation pressure that occurs after mass mortalities of less tolerant species (Hrs-Brenko 2006). The temporal increase in the frequency of hypoxia was also associated with higher sediment pollution by metals, and this probably delayed the immigration of the otherwise hypoxia-tolerant invasive species Anadara transversa (Albano et al. 2018).

Warming plays a significant role in promoting water-column stratification (Degobbis et al. 2000) and in the formation of mucilages in the northern Adriatic Sea (Danovaro et al. 2009), and its effects on the frequency of hypoxia and abundances of $C$. gibba were detected over longer, centennial timescales (Tomašových et al. 2017). However, the link between temperature increase that took place during the twentieth century and the outbreaks of $C$. gibba is weaker, probably because eutrophication increased the probability of oxygen depletion even under colder conditions and multiple other factors contribute to the onset of major hypoxic crises in the northern Adriatic Sea (Alvisi and Cozzi 2016). For example, the 1977 hypoxic event correlated with low barometric pressure and an exceptionally high freshwater input (Degobbis et al. 1979; Stefanon and Boldrin 1982). In contrast, the 1989 hypoxic event correlated with lower Po discharge but with high barometric pressure and prolonged duration of stratification (Supić et al. 2000). Therefore, the role of nutrient enrichment probably added to the effects of climate in generating some hypoxic events in the late twentieth century.

The lack of relation to the river discharge, in contrast to the frequency of hypoxia, indicates that the effects of floods, potentially increasing sediment instability, were not important in determining the temporal increase in abundance of C. gibba. The role of other anthropogenic stressors that can account for the increase in abundance of $C$. gibba, such as an increase in dredging and trawling that slows recovery of communities in the Gulf of Trieste and contributes to sediment instability (Stachowitsch 1991; Lotze et al. 2011; Mautner et al. 2018), is probably less important, because trawling and dredging activity would increase time averaging and destroy flood-event stratification in the sediment via higher frequency of sediment reworking.

The associations between higher abundance of C. gibba on one hand and higher TOC and reduced bioturbation in sedimentary sequences on the other hand (leading to reduced stratigraphic disorder and time averaging) thus indicate that the outbreaks by C. gibba reflect a community-level response to eutrophication and increased frequency of hypoxia in the twentieth century. During this shift, the balance between preservation and postdepositional modification, originally in favor of bioturbational destruction under normoxic conditions, shifted toward the preservation of flood layers and reduced bioturbation under more frequent hypoxic conditions. This change probably led to less efficient bioirrigation and smaller sediment heterogeneity (e.g., Mermillod-Blondin 2011), reduced biogeochemical cycling (e.g., Lohrer et al. 2004; Braeckman et al. 2010), and less efficient bentho-pelagic coupling (e.g., Gray et al. 2002). This change in bioturbational mixing also allowed preservation of ecological changes in sediment cores.

\section{Conclusions}

Temporal resolution and disorder distinguished on the basis of age-frequency distributions show that down-core changes in resolution are driven by changes in 
bioturbation rather than by changes in sedimentation rates. The late twentieth-century interval in sediment cores of the northern Adriatic Sea is associated with decreasing abundance of formerly abundant mollusks and with outbreaks of the opportunistic bivalve Corbula gibba. We thus validate previous inferences of significant changes in the composition of soft-bottom macrobenthic communities in circalittoral, oligophotic, or aphotic habitats based on heterogeneous and irregular sampling of living assemblages that were collected during the twentieth century. However, we show for the first time that these compositional changes were associated with declining thickness of the surface mixed layer and increasing preservation of organic matter, that these changes in bioturbation can be detected by changes in time averaging and disorder, and that the shift occurred relatively abruptly at around A.D. 1950. The relations between unmixed abundance of $C$. gibba and minimum dissolved oxygen concentrations at Po and Panzano imply that this major depositional and ecosystem regime shift was driven by higher frequency of hypoxic events in the late twentieth century, probably triggered by anthropogenic nutrient enrichment, over a broad spatial extent in the NW and NE Adriatic Sea. This shift effectively separates the sediments of the late twentieth-century eutrophication period from sediments of the early twentieth century that are similar to highstand deposits of the Po prodelta, which are typically pervasively bioturbated. The association of $C$. gibba outbreaks with reduced bioturbation indicates that the hypoxic events modified not only the composition of bivalve communities over broad spatial scales but also altered biogeochemical fluxes at the sedimentwater interface by reducing the depth of the mixed layer.

\section{Acknowledgments}

We thank M. Aberhan, L. C. Anderson, and one anonymous reviewer for comments. This study was funded by the Austrian Science Fund (FWF project P24901), the Slovak Research and Development Agency (APVV 17-0555), and the Slovak Grant Agency (VEGA
0136-15). We thank J. Sedmak and F. Perco for help with sampling, D. A. Garcia Ramos for help with determination of trace fossils, and $\mathrm{K}$. Whitacre for amino acid analyses. The authors would like to thank to M. Celio of ARPAFVG for onboard activities and hydrological data.

\section{Literature Cited}

Albano, P. G., I. Gallmetzer, A. Haselmair, A. Tomašových, M. Stachowitsch, and M. Zuschin. 2018. Historical ecology of a biological invasion: the interplay of eutrophication and pollution determines time lags in establishment and detection. Biological Invasions 20:1417-143.

Aleffi, F., and N. Bettoso. 2000. Distribution of Corbula gibba (Bivalvia, Corbulidae) in the northern Adriatic Sea. Annales, Series Historia Naturalis 10:173-180.

Allen, A. P., M. A. Kosnik, and D. S. Kaufman. 2013. Characterizing the dynamics of amino acid racemization using time-dependent reaction kinetics: a Bayesian approach to fitting agecalibration models. Quaternary Geochronology 18:63-77.

Aller, R. C. 1994. Bioturbation and remineralization of sedimentary organic matter: effects of redox oscillation. Chemical Geology 114:331-345.

Alvisi, F., and S. Cozzi. 2016. Seasonal dynamics and long-term trend of hypoxia in the coastal zone of Emilia Romagna (NW Adriatic Sea, Italy). Science of the Total Environment 541:14481462

Amorosi, A., E. Dinelli, V. Rossi, S. C. Vaiani, and M. Sacchetto. 2008. Late Quaternary palaeoenvironmental evolution of the Adriatic coastal plain and the onset of Po River Delta. Palaeogeography, Palaeoclimatology, Palaeoecology 268:80-90.

Amorosi, A., V. Maselli, and F. Trincardi. 2016. Onshore to offshore anatomy of a late Quaternary source-to-sink system (Po PlainAdriatic Sea, Italy). Earth-Science Reviews 153:212-237.

Anderson, L. C., and P. D. Roopnarine. 2003. Evolution and phylogenetic relationships of Neogene Corbulidae (Bivalvia; Myoidea) of tropical America. Journal of Paleontology 77:1086-1102.

Anderson, M. 2001. A new method for non-parametric multivariate analysis of variance. Austral Ecology 26:32-46.

Atkinson, R. J. A., and C. Froglia. 2000. Burrow structures and ecoethology of burrowing fauna in the Adriatic Sea. Pp. 79-94 in O. Giovanardi, ed. Impact of trawl fishing on benthic communities. Istituto Centrale per la Ricerca Scientifica e Tecnologica Applicata al Mare, Rome.

Barmawidjaja, D. M., G. J. Van der Zwaan, F. J. Jorissen, and S. Puskaric. 1995. 150 years of eutrophication in the northern Adriatic Sea: evidence from a benthic foraminiferal record. Marine Geology 122:367-384.

Beguería, S., and Y. Pueyo. 2009. A comparison of simultaneous autoregressive and generalized least squares models for dealing with spatial autocorrelation. Global Ecology and Biogeography 18:273-279.

Bentley, S. J., and C. A. Nittrouer. 2012. Accumulation and intense bioturbation of bioclastic muds along a carbonate-platform margin: Dry Tortugas, Florida. Marine Geology 315:44-57.

Bentley, S. J., and A. Sheremet. 2003. New model for the emplacement, bioturbation, and preservation of fine-scaled sedimentary strata. Geology 31:725-728.

Bentley, S. J., A. Sheremet, and J. M. Jaeger. 2006. Event sedimentation, bioturbation, and preserved sedimentary fabric: field and model comparisons in three contrasting marine settings. Continental Shelf Research 26:2108-2124.

Berkeley, A., C. T. Perry, S. G. Smithers, B. P. Horton, and K. G. Taylor. 2007. A review of the ecological and taphonomic controls 
on foraminiferal assemblage development in intertidal environments. Earth-Science Reviews 83:205-230.

Beukema, J. J., and G. C. Cadée. 1991. Growth rates of the bivalve Macoma balthica in the Wadden Sea during a period of eutrophication: relationships with concentrations of pelagic diatoms and flagellates. Marine Ecology Progress Series 68:249-256.

Boudreau, B. P. 1994. Is burial velocity a master parameter for bioturbation? Geochimica et Cosmochimica Acta 58:1243-1249.

Braeckman, U., P. Provoost, B. Gribsholt, D. Van Gansbeke, J. J. Middelburg, K. Soetaert, M. Vincx, and J. Vanaverbeke. 2010. Role of macrofauna functional traits and density in biogeochemical fluxes and bioturbation. Marine Ecology Progress Series 399:173-186.

Breitburg, D., L.A. Levin, A. Oschlies, M. Grégoire, F. P. Chavez, D. J. Conley, V. Garçon, D. Gilbert, D. Gutiérrez, K. Isensee, G. S. Jacinto, K. E. Limburg, I. Montes, S. W. A. Naqvi, G. C. Pitcher, N. N. Rabalais, M. R. Roman, K. A. Rose, B. A. Seibel, M. Telszewski, M. Yasuhara, and J. Zhang. 2018. Declining oxygen in the global ocean and coastal waters. Science 359:eaam7240.

Briggs, K. B., V. A. Hartmann, K. M. Yeager, S. Shivarudrappa, R. J. Díaz, L. E. Osterman, and A. H. Reed. 2015. Influence of hypoxia on biogenic structure in sediments on the Louisiana continental shelf. Estuarine, Coastal and Shelf Science 164:147-160.

Burdige, D. J. 2007. Preservation of organic matter in marine sediments: controls, mechanisms, and an imbalance in sediment organic carbon budgets? Chemical Reviews 107:467-485.

Carstensen, J., J. H. Andersen, B. G. Gustafsson, and D. J. Conley. 2014. Deoxygenation of the Baltic Sea during the last century. Proceedings of the National Academy of Sciences USA 111:56285633.

Chiantore, M., D. Bedulli, R. Cattaneo-Vietti, S. Schiaparelli, and G. Albertelli. 2001. Long-term changes in the Mollusc-Echinoderm assemblages in the north and coastal middle Adriatic Sea. Atti della Associazione Italiana di Oceanologia e Limnologia 14:63-75.

Cibic, T., O. Blasutto, and N. Bettoso. 2009. Microalgal-meiofaunal interactions in a sublittoral site of the Gulf of Trieste (northern Adriatic Sea, Italy): a three-year study. Journal of Experimental Marine Biology and Ecology 370:144-154.

Cibic, T., C. Comici, A. Bussani, and P. Del Negro. 2012. Benthic diatom response to changing environmental conditions. Estuarine, Coastal and Shelf Science 115:158-169.

Coma, R., M. Ribes, E. Serrano, E. Jiménez, J. Salat, and J. Pascuals. 2009. Global warming - enhanced stratification and mass mortality events in the Mediterranean. Proceedings of National Academy of Sciences USA 106:6176-6181.

Correggiari, A., A. Cattaneo, and F. Trincardi. 2005. The modern Po Delta system: lobe switching and asymmetric prodelta growth. Marine Geology 222:49-74.

Covelli, S., G. Fontolan, J. Faganeli, and N. Ogrinc. 2006. Anthropogenic markers in the Holocene stratigraphic sequence of the Gulf of Trieste (northern Adriatic Sea). Marine Geology 230:2951.

Cozzi, S., C. Falconi, C. Comici, B. Čermelj, N. Kovac, V. Turk, and M. Giani. 2012. Recent evolution of river discharges in the Gulf of Trieste and their potential response to climate changes and anthropogenic pressure. Estuarine, Coastal and Shelf Science 115:14-24.

Cramer, K. L., J. B. Jackson, C. V. Angioletti, J. Leonard-Pingel, and T. P. Guilderson. 2012. Anthropogenic mortality on coral reefs in Caribbean Panama predates coral disease and bleaching. Ecology Letters 15:561-567.

Crema, R., A. Castelli, and D. Prevedelli. 1991. Long term eutrophication effects on macrofaunal communities in northern Adriatic Sea. Marine Pollution Bulletin 22:503-508.

Cutler, A. H., and K. W. Flessa. 1990. Fossils out of sequence: computer simulations and strategies for dealing with stratigraphic disorder. Palaios 5:227-235.
Danovaro, R., S. F. Umani, and A. Pusceddu. 2009. Climate change and the potential spreading of marine mucilage and microbial pathogens in the Mediterranean Sea. PLoS ONE 4:e7006.

Degobbis, D., N. Smodlaka, I. Pojed, A. Škrivanić, and R. Precali. 1979. Increased eutrophication of the northern Adriatic Sea. Marine Pollution Bulletin 10:298-301.

Degobbis, D., R. Precali, I. Ivancic, N. Smodlaka, D. Fuks, and S. Kveder. 2000. Long-term changes in the northern Adriatic ecosystem related to anthropogenic eutrophication. International Journal of Environment and Pollution 13:495-533.

Diaz, R. J., and R. Rosenberg. 1995. Marine benthic hypoxia: a review of its ecological effects and the behavioural responses of benthic macrofauna. Oceanography and Marine Biology: An Annual Review 33:245-303.

Djakovac, T., N. Supić, F. B. Aubry, D. Degobbis, and M. Giani. 2015. Mechanisms of hypoxia frequency changes in the northern Adriatic Sea during the period 1972-2012. Journal of Marine Systems 141:179-189.

Dominguez, J. G., M. A. Kosnik, A. P. Allen, Q. Hua, D. E. Jacob, D. S. Kaufman, and K. Whitacre. 2016. Time-averaging and stratigraphic resolution in death assemblages and Holocene deposits: Sydney Harbour's molluscan record. Palaios 31:564-575.

Dominici, S. 2001. Taphonomy and paleoecology of shallow marine macrofossil assemblages in a collisional setting (late Plioceneearly Pleistocene, western Emilia, Italy). Palaios 16:336-353.

Faganeli, J., A. Avčin, N. Fanuko, A. Malej, V. Turk, P. Tušnik, B. Vrišer, and A. Vukovič. 1985. Bottom layer anoxia in the central part of the Gulf of Trieste in the late summer of 1983. Marine Pollution Bulletin 16:75-78

Federico, G., and P. Malanima. 2004. Progress, decline, growth: product and productivity in Italian agriculture, 1000-2000. Economic History Review 57:1-437.

Fedra, K., E. M. Ölscher, C. Scherübel, M. Stachowitsch, and R. S. Wurzian. 1976. On the ecology of a North Adriatic benthic community: distribution, standing crop and composition of the macrobenthos. Marine Biology 38:129-145.

Flessa, K. W., and M. Kowalewski. 1994. Shell survival and timeaveraging in nearshore and shelf environments: estimates from the radiocarbon literature. Lethaia 27:153-165.

Franzo, A., T. Cibic, P. Del Negro, and C. De Vittor. 2015. Spatial distribution of microphytobenthos, meiofauna and macrofauna in the north-western Adriatic Sea: a synoptic study. Advances in Oceanography and Limnology 6:58-75.

Frignani, M., L. Langone, M. Ravaioli, D. Sorgente, F. Alvisi, and S. Albertazzi. 2005. Fine-sediment mass balance in the western Adriatic continental shelf over a century time scale. Marine Geology 222:113-133.

Gacic, M., G. Civitarese, and L. Ursella. 1999. Spatial and seasonal variability of water and biogeochemical fluxes in the Adriatic Sea. NATO Science Series 2 Environmental Security 51:335-358.

Gallmetzer, I., A. Haselmair, M. Stachowitsch, and M. Zuschin. 2016. An innovative piston corer for large-volume sediment samples. Limnology and Oceanography: Methods 14:698-717.

Gallmetzer, I., A. Haselmair, A. Tomašových, M. Stachowitsch, and M. Zuschin, M. 2017. Responses of molluscan communities to centuries of human impact in the northern Adriatic Sea. PLoS ONE 12:e180820.

Giani, M., T. Djakovac, D. Degobbis, S. Cozzi, C. Solidoro, and S. F. Umani. 2012. Recent changes in the marine ecosystems of the northern Adriatic Sea. Estuarine, Coastal and Shelf Science 115:1-13.

Gofas, S. 2008. Corbula gibba (Olivi, 1792). In: MolluscaBase (2017). www.marinespecies.org/aphia.php?p=taxdetails\&id=139410, accessed: 30 May 2018.

Gogina, M., A. A. Darr, and M. L. Zettler. 2014. Approach to assess consequences of hypoxia disturbance events for benthic ecosystem functioning. Journal of Marine Systems 129:203-213. 
Gooday, A. J., F. Jorissen, L. A. Levin, J. J. Middelburg, S. W. A. Naqvi, N. N. Rabalais, M. Scranton, M., and J. Zhang. 2009. Historical records of coastal eutrophication-induced hypoxia. Biogeosciences 6:1707-1745.

Gray, J. S., R. S. S. Wu, and Y. Y. Or. 2002. Effects of hypoxia and organic enrichment on the coastal marine environment. Marine Ecology Progress Series 238:249-279.

Harding, L. W., D. Degobbis, and R. Precali. 1999. Production and fate of phytoplankton: annual cycles and interannual variability. Pp. 131-172 in T. C. Malone, A. Malej, L. W. Harding, N. Smodlaka, and R. E. Turner, eds. Ecosystems at the land-sea margin: drainage basin to coastal sea. American Geophysical Union, Washington, D.C.

Hrs-Brenko, M. 2006. The basket shell, Corbula gibba Olivi, 1792 (bivalve mollusks) as a species resistant to environmental disturbances: a review. Acta Adriatica 47:49-64.

Hrs-Brenko, M., D. Medaković, Ž. Labura, and E. Zahtila. 1994. Bivalve recovery after a mass mortality in the autumn of 1989 in the northern Adriatic Sea. Periodicum Biologorum 96:455-459.

Hull, P. M., P. J. Franks, and R. D. Norris. 2011. Mechanisms and models of iridium anomaly shape across the Cretaceous-Paleogene boundary. Earth and Planetary Science Letters 301:98-106.

Jackson, C. H. 2011. Multi-state models for panel data: the msm package for R. Journal of Statistical Software 38:1-29.

Johannessen, S. C., and R. W. Macdonald. 2012. There is no 1954 in that core! Interpreting sedimentation rates and contaminant trends in marine sediment cores. Marine Pollution Bulletin 64:675-678.

Jones, N. S. 1956. The fauna and biomass of a muddy sand deposit off Port Erin, Isle of Man. Journal of Animal Ecology 25:217-252.

Justić, D. 1991. Hypoxic conditions in the northern Adriatic Sea: historical development and ecological significance. Geological Society of London Special Publication 58:95-105.

Justić, D., T. Legović, and L. Rottini-Sandrini. 1987. Trends in oxygen content 1911-1984 and occurrence of benthic mortality in the northern Adriatic Sea. Estuarine, Coastal and Shelf Science 25:435-445.

Kaufman, D. S., and W. F. Manley 1998. A new procedure for determining DL amino acid ratios in fossils using reverse phase liquid chromatography. Quaternary Science Reviews 17:9871000.

Kidwell, S. M. 2015. Biology in the Anthropocene: challenges and insights from young fossil records. Proceedings of the National Academy of Sciences USA 112:4922-4929.

Kidwell, S. M., M. M. Best, and D. S. Kaufman. 2005. Taphonomic trade-offs in tropical marine death assemblages: differential time averaging, shell loss, and probable bias in siliciclastic vs. carbonate facies. Geology 33:729-732.

Kosnik, M. A., and D. S. Kaufman. 2008. Identifying outliers and assessing the accuracy of amino acid racemization measurements for geochronology: II. Data screening. Quaternary Geochronology 3:328-341.

Kosnik, M. A., Q. Hua, G. E. Jacobsen, D. S. Kaufman, and R. A. Wüst. 2007. Sediment mixing and stratigraphic disorder revealed by the age-structure of Tellina shells in Great Barrier Reef sediment. Geology 35:811-814.

Kosnik, M. A., Q. Hua, D. S. Kaufman, and A. Zawadzki. 2015. Sediment accumulation, stratigraphic order, and the extent of time-averaging in lagoonal sediments: a comparison of ${ }^{210} \mathrm{~Pb}$ and ${ }^{14} \mathrm{C} /$ amino acid racemization chronologies. Coral Reefs 34:215229.

Kowalewski, M., G. A. Goodfriend, and K. W. Flessa. 1998. Highresolution estimates of temporal mixing within shell beds: the evils and virtues of time-averaging. Paleobiology 24:287-304.

Kowalewski, M., J. M. Wittmer, T. A. Dexter, A. Amorosi, and D. Scarponi. 2015. Differential responses of marine communities to natural and anthropogenic changes. Proceedings of the Royal Society of London B 282:20142990.
Kristensen, E. 2000. Organic matter diagenesis at the oxic/anoxic interface in coastal marine sediments, with emphasis on the role of burrowing animals. Hydrobiologia 426:1-24.

Lohrer, A. M., S. F. Thrush, and M. M. Gibbs. 2004. Bioturbators enhance ecosystem function through complex biogeochemical interactions. Nature 431:1092-1095.

Lotze, H. K., H. S. Lenihan, B. J. Bourque, R. H. Bradbury, R. G. Cooke, M.C. Kay, S. M. Kidwell, M. X. Kirby, C. H. Peterson, and J. B. Jackson. 2006. Depletion, degradation, and recovery potential of estuaries and coastal seas. Science 312:1806-1809.

Lotze, H. K., M. Coll, and J. A. Dunne. 2011. Historical changes in marine resources, food-web structure and ecosystem functioning in the Adriatic Sea, Mediterranean. Ecosystems 14:198-222.

Loubere, P., and A. Gary. 1990. Taphonomic process and species microhabitats in the living to fossil assemblage transition of deeper water benthic foraminifera. Palaios 5:375-381.

Löwemark, L., K. I. Konstantinou, and S. Steinke. 2008. Bias in foraminiferal multispecies reconstructions of paleohydrographic conditions caused by foraminiferal abundance variations and bioturbational mixing: a model approach. Marine Geology 256:101-106.

MacEachern, J. A., K. L. Bann, J. P. Bhattacharya, and C. D. Howell, Jr. 2005. Ichnology of deltas: organism responses to the dynamic interplay of rivers, waves, storms, and tides. In L. Giosan, and J. P. Bhattacharya, eds. River deltas-concepts, models, and examples (SEPM Special Publication 83 49-85. Society for Sedimentary Geology, Tulsa, Okla.

Malej, A., and V. Malacic. 1995. Factors affecting bottom layer oxygen depletion in the Gulf of Trieste (Adriatic Sea). Annales, Series Historia Naturalis 6:33-42.

Marchetti, R., A. Provini, and G. Crosa. 1989. Nutrient load carried by the River Po into the Adriatic Sea, 1968-1987. Marine Pollution Bulletin 20:168-172.

Mautner, A. K., I. Gallmetzer, A. Haselmair, S. M. Schnedl, A. Tomašových, and M. Zuschin, M. 2018. Holocene ecosystem shifts and human-induced loss of Arca and Ostrea shell beds in the north-eastern Adriatic Sea. Marine Pollution Bulletin 126:19-30.

Mavrič, B., M. Orlando-Bonaca, N. Bettoso, and L. Lipej. 2010. Softbottom macrozoobenthos of the southern part of the Gulf of Trieste: faunistic, biocoenotic and ecological survey. Acta Adriatica 51:203-216.

Mermillod-Blondin, F. 2011. The functional significance of bioturbation and biodeposition on biogeochemical processes at the water-sediment interface in freshwater and marine ecosystems. Journal of the North American Benthological Society 30:770-778.

Meysman, F. J., B. P. Boudreau, and J. J. Middelburg 2010. When and why does bioturbation lead to diffusive mixing? Journal of Marine Research 68:881-920.

Miserocchi, S., L. Langone, and T. Tesi. 2007. Content and isotopic composition of organic carbon within a flood layer in the Po River prodelta (Adriatic Sea). Continental Shelf Research 27:338358.

NationMaster. 2018. Agriculture: Fertilizer Use. www.nationmas ter.com/country-info/stats/Agriculture/Fertilizer-use, accessed: 30 May 2018.

Nerlović, V., A. Doğan, and M. Hrs-Brenko. 2011. Response to oxygen deficiency (depletion): bivalve assemblages as an indicator of ecosystem instability in the northern Adriatic Sea. Biologia 66:1114-1126.

Nerlović, V., M. Hrs-Brenko, and A. Dogan. 2012. Long-term changes in the transitional community of detritic bottoms of the Northern Adriatic Sea: dynamic of the bivalve assemblages. Fresenius Environmental Bulletin 21:3600-3613.

Notar, M., H. Leskovšek, and J. Faganeli. 2001. Composition, distribution and sources of polycyclic aromatic hydrocarbons in sediments of the Gulf of Trieste, Northern Adriatic Sea. Marine Pollution Bulletin 42:36-44. 
N'Siala, G. M., V. Grandi, M. Iotti, G. Montanari, D. Prevedelli, and R. Simonini. 2008. Responses of a northern Adriatic Ampelisca-Corbula community to seasonality and short-term hydrological changes in the Po river. Marine Environmental Research 66:466-476.

Occhipinti-Ambrogi, A., M. Favruzzo, and D. Savini. 2002. Multiannual variations of macrobenthos along the Emilia-Romagna coast (northern Adriatic). Marine Ecology 23:307-319.

Occhipinti-Ambrogi, A., D. Savini, and G. Forni. 2005. Macrobenthos community structural changes off Cesenatico coast (Emilia Romagna, northern Adriatic), a six-year monitoring programme. Science of the Total Environment 353:317-328.

Ogrinc, N., and J. Faganeli. 2006. Phosphorus regeneration and burial in near-shore marine sediments (the Gulf of Trieste, northern Adriatic Sea). Estuarine, Coastal and Shelf Science 67:579-588.

Olszewski, T. D. 2004. Modeling the influence of taphonomic destruction, reworking, and burial on time-averaging in fossil accumulations. Palaios 19:39-50.

Orange, D., A. García-García, T. Lorenson, C. Nittrouer, T. Milligan, S. Miserocchi, L. Langone, A. Correggiari, and F. Trincardi. 2005. Shallow gas and flood deposition on the Po Delta. Marine Geology 222:159-177.

Orel, G., and B. Mennea. 1969. I popolamenti bentonici di alcuni tipi di fondo mobile del Golfo di Trieste. Pubblicazioni della Stazione Zoologica di Napoli 37(Suppl. 2), 261-276.

Palinkas, C. M., and C. A. Nittrouer. 2007. Modern sediment accumulation on the Po shelf, Adriatic Sea. Continental Shelf Research 27:489-505.

Pandolfi, J. M., and J. B. Jackson. 2006. Ecological persistence interrupted in Caribbean coral reefs. Ecology Letters 9:818-826.

Parsons-Hubbard, K., D. Hubbard, C. Tems, and A. Burkett. 2014. The relationship between modern mollusk assemblages and their expression in subsurface sediment in a carbonate lagoon, St. Croix, US Virgin Islands. Pp. 143-167 in. Experimental approaches to understanding fossil organisms. Springer, Dordrecht, Netherlands.

Pervesler, P., and P. C. Dworschak. 1985. Burrows Oijaxea nocturna Nardo in the Gulf of Trieste. Senckenbergiana Maritima 17:33-53.

Pervesler, P., and J. Hohenegger. 2006. Orientation of crustacean burrows in the Bay of Panzano (Gulf of Trieste, northern Adriatic Sea). Lethaia 39:173-186.

Price, A. M., M. M. Baustian, R. E. Turner, N. N. Rabalais, and G. L. Chmura. 2018. Dinoflagellate cysts track eutrophication in the Northern Gulf of Mexico. Estuaries and Coasts 41. doi.org/10.1007/s12237-017-0351-x.

Rabalais, N. N., R. E. Turner, R. J. Diaz, and D. Justić. 2009. Global change and eutrophication of coastal waters. ICES Journal of Marine Science 66:1528-1537.

Rayner, N. A., D. E. Parker, E. B. Horton, C. K. Folland, L. V. Alexander, D. P. Rowell, E. C. Kent, and A. Kaplan. 2003. Global analyses of sea surface temperature, sea ice, and night marine air temperature since the late nineteenth century. Journal of Geophysical Research 108:4407.

Riedel, B., M. Zuschin, and M. Stachowitsch. 2012. Tolerance of benthic macrofauna to hypoxia and anoxia in shallow coastal seas: a realistic scenario. Marine Ecology Progress Series 458:39-52.

Rinaldi, A., G. Montanari, A. Ghetti, and C. R. Ferrari. 1992. Anossie nelle acque costiere dell'Adriatico Nord-Occidentale, Loro evoluzione e conseguenze sull'ecosistema bentonico. Biologia Marina, Suppl. Notiziario Societa Italiana di Biologia Marina 1:79-89.

Ritter, M. N., F. Erthal, M. A. Kosnik, J. C. Coimbra, and D. S. Kaufman. 2017. Spatial variation in the temporal resolution of subtropical shallow-water molluscan death assemblages. Palaios 32:572-583.

Sanchez-Cabeza, J. A., and A. C. Ruiz-Fernández. 2012. ${ }^{210} \mathrm{~Pb}$ sediment radiochronology: an integrated formulation and classification of dating models. Geochimica et Cosmochimica Acta 82:183-200.

Sangiorgi, F., and T. H. Donders. 2004. Reconstructing 150 years of eutrophication in the north-western Adriatic Sea (Italy) using dinoflagellate cysts, pollen and spores. Estuarine, Coastal and Shelf Science 60:69-79.

Savrda, C. E., and D. J. Bottjer. 1991. Oxygen-related biofacies in marine strata: an overview and update. Geological Society of London Special Publication 58:201-219.

Scardi, M., R. Crema, P. Di Dato, E. Fresi, and G. Orel. 2000. Le comunità bentoniche dell'Alto Adriatico: un'analisi preliminare dei cambiamenti strutturali dagli anni'30 ad oggi. Pp. 95-108 in O. Giovanardi, ed. Impact of trawl fishing on benthic communities. Istituto Centrale per la Ricerca Scientifica e Tecnologica Applicata al Mare, Rome.

Scarponi, D., and M. Kowalewski. 2004. Stratigraphic paleoecology: bathymetric signatures and sequence overprint of mollusk associations from upper Quaternary sequences of the Po Plain, Italy. Geology 32:989-992.

- 2007. Sequence stratigraphic anatomy of diversity patterns: Late Quaternary benthic mollusks of the Po Plain, Italy. Palaios 22:296-305.

Scarponi, D., D. S. Kaufman, A. Amorosi, and M. Kowalewski. 2013. Sequence stratigraphy and the resolution of the fossil record. Geology 41:239-242.

Schiffelbein, P. 1985. Extracting the benthic mixing impulse response function: A constrained deconvolution technique. Marine Geology 64:313-336.

Schinner, G. O. 1993. Burrowing behavior, substratum preference, and distribution of Schizaster canaliferus (Echinoidea: Spatangoida) in the northern Adriatic Sea. Marine Ecology 14:129145.

Siché, I., and G. Arnaud-Fassetta. 2014. Anthropogenic activities since the end of the Little Ice Age: a critical factor driving fluvial changes on the Isonzo River (Italy, Slovenia). Méditerranée 122:183-199.

Simonini, R., I. Ansaloni, A. B. Pagliai, and D. Prevedelli. 2004 Organic enrichment and structure of the macrozoobenthic community in the northern Adriatic Sea in an area facing Adige and Po mouths. ICES Journal of Marine Science 61: 871-881.

Smith, C. R., and C. Rabouille. 2002. What controls the mixed-layer depth in deep-sea sediments? The importance of POC flux. Limnology and Oceanography 47:418-426.

Solan, M., P. Batty, M. T. Bulling, and J. A. Godbold. 2008. How biodiversity affects ecosystem processes: implications for ecological revolutions and benthic ecosystem function. Aquatic Biology 2:289-301.

Solis-Weiss, V., P. Rossin, F. Aleffi, N. Bettoso, and S. Fonda Umani. 2004. A regional GIS for benthic diversity and environmental impact studies in the Gulf of Trieste, Italy. Pp. 245-255 in E. Van den Berghe, ed. Proceedings of the Colour of Ocean Data: International Symposium on Oceanographic Data and Information Management with Special Attention to Biological Data (IOC Workshop Report 188). UNESCO, Paris.

Sommerfield, C. K. 2006. On sediment accumulation rates and stratigraphic completeness: lessons from Holocene ocean margins. Continental Shelf Research 26:2225-2240.

Stachowitsch, M. 1984. Mass mortality in the Gulf of Trieste: the course of community destruction. Marine Ecology 5:243-264.

- 1991. Anoxia in the Northern Adriatic Sea: rapid death, slow recovery. Geological Society of London Special Publication 58:119-129.

Stefanon, A. T., and A. Boldrin. 1982. The oxygen crisis of the northern Adriatic Sea waters in late fall 1977 and its effects on benthic communities. Pp. 167-175 in J. Blanchard, J. Mair, and I. Morrison, eds. Proceedings of the 6th International Science 
Symposium of the World Underwater Federation. National Environmental Research Council, Edinburgh.

Steiner, Z., B. Lazar, S. Levi, S. Tsroya, O. Pelled, R. Bookman, and J. Erez. 2016. The effect of bioturbation in pelagic sediments: lessons from radioactive tracers and planktonic foraminifera in the Gulf of Aqaba, Red Sea. Geochimica et Cosmochimica Acta 194:139-152.

Supić, N., M. Orlić, and D. Degobbis. 2000. Istrian Coastal Countercurrent and its year-to-year variability. Estuarine, Coastal and Shelf Science 51:385-397.

Tesi, T., S. Miserocchi, M. A. Goñi, M. Turchetto, L. Langone, A. De Lazzari, S. Albertazzi, and A. Correggiari. 2011. Influence of distributary channels on sediment and organic matter supply in event-dominated coastal margins: the Po prodelta as a study case. Biogeosciences 8:365-385.

Tesi, T., L. Langone, M. A. Goni, R. A. Wheatcroft, S. Miserocchi, and L. Bertotti. 2012. Early diagenesis of recently deposited organic matter: a 9-yr time-series study of a flood deposit. Geochimica et Cosmochimica Acta 83:19-36.

Thrush, S. F., and P. K. Dayton. 2002. Disturbance to marine benthic habitats by trawling and dredging: implications for marine biodiversity. Annual Review of Ecology and Systematics 33:449473

Traykovski, P., P. L. Wiberg, and W. R. Geyer. 2007. Observations and modeling of wave-supported sediment gravity flows on the Po prodelta and comparison to prior observations from the Eel shelf. Continental Shelf Research 27:375-399.

Tomašových, A., and S. M. Kidwell. 2010. The effects of temporal resolution on species turnover and on testing metacommunity models. American Naturalist 175:587-606.

_ 2017. Nineteenth-century collapse of a benthic marine ecosystem on the open continental shelf. Proceedings of the Royal Society of London B 284:20170328.

Tomašových, A., S. M. Kidwell, R. Foygel Barber, and D. S. Kaufman. 2014. Long-term accumulation of carbonate shells reflects a 100-fold drop in loss rate. Geology 42:819-822.

Tomašových, A., S. M. Kidwell, and R. Foygel Barber. 2016. Inferring skeletal production from time-averaged assemblages: skeletal loss pulls the timing of production pulses towards the modern period. Paleobiology 42:54-76.

Tomašových, A., I. Gallmetzer, A. Haselmair, D. S. Kaufman, J. Vidović, and M. Zuschin. 2017. Stratigraphic unmixing reveals repeated hypoxia events over the past $500 \mathrm{yr}$ in the northern Adriatic Sea. Geology 45:363-366.

Vatova, A. 1935. Ricerche preliminari sulle biocenosi del Golfo di Rovigno. Thalassia 2:1-30.

— 1949. La fauna bentonica dell'alto e medio Adriatico. Nova Thalassia 1:1-110.

Vidakovic, J., and D. Zavodnik. 1984. Benthos of the Po River mouth-subject to stress conditions? Pp. 805-808 in VIIes Journees d'Etudes sur les Pollutions Marines en Mediterranee. Commission Internationale pour l'Exploration Scientifique de la Mer Mediterranee, Monaco.

Vidović, J., R. Nawrot, I. Gallmetzer, A. Haselmair, A. Tomašových, M. Stachowitsch, V. Ćosović, and M. Zuschin 2016. Anthropogenically induced environmental changes in the northeastern Adriatic Sea in the last 500 years (Panzano Bay, Gulf of Trieste). Biogeosciences 13:5965-5981.

Villnäs, A., J. Norkko, K. Lukkari, J. Hewitt, and A. Norkko. 2012. Consequences of increasing hypoxic disturbance on benthic communities and ecosystem functioning. PLoS ONE 7:e44920.

Virtasalo, J. J., T. Leipe, M. Moros, and A. T. Kotilainen. 2011. Physicochemical and biological influences on sedimentary-fabric formation in a salinity and oxygen-restricted semi-enclosed sea: Gotland Deep, Baltic Sea. Sedimentology 58:352-375.

Walbran, P. D., R. A. Henderson, J. W. Faithful, H. A. Polach, R. J. Sparks, G. Wallace, and D. C. Lowe. 1989. Crown-of-thorns starfish outbreaks on the Great Barrier Reef: a geological perspective based upon the sediment record. Coral Reefs 8:67-78.

Wetzel, A., R. Tjallingii, and M. G. Wiesner. 2011. Bioturbational structures record environmental changes in the upwelling area off Vietnam (South China Sea) for the last 150,000 years. Palaeogeography, Palaeoclimatology, Palaeoecology 311:256-267.

Wheatcroft, R. A. 1990. Preservation potential of sedimentary event layers. Geology 18:843-845.

Wheatcroft, R. A., and D. E. Drake. 2003. Post-depositional alteration and preservation of sedimentary event layers on continental margins, I. The role of episodic sedimentation. Marine Geology 199:123-137.

Wheatcroft, R. A., A. W. Stevens, L. M. Hunt, and T. G. Milligan 2006. The large-scale distribution and internal geometry of the fall 2000 Po River flood deposit: evidence from digital X-radiography. Continental Shelf Research 26:499-516.

Wheatcroft, R. A., P. L. Wiberg, C. R. Alexander, S. J. Bentley, D. E. Drake, C. K. Harris, and A. S. Ogston 2007. Post-depositional alteration and preservation of sedimentary strata. Pp. 101-155 in C. A. Nittrouer, J. A. Austin, M. E. Field, J. H. Kravitz, J. P. M. Syvitski, and P. L. Wiberg, eds. Continental margin sedimentation: from sediment transport to sequence stratigraphy. Blackwell, Oxford.

Willis, K. J., M. B. Araújo, K. D. Bennett, B. Figueroa-Rangel, C. A. Froyd, and N. Myers. 2007. How can a knowledge of the past help to conserve the future? Biodiversity conservation and the relevance of long-term ecological studies. Philosophical Transactions of the Royal Society of London B 362:175-187.

Wittmer, J. M., T. A. Dexter, D. Scarponi, A. Amorosi, and M. Kowalewski. 2014. Quantitative bathymetric models for late Quaternary transgressive-regressive cycles of the Po Plain, Italy. Journal of Geology 122:649-670.

Wolfe, A. P., W.O. Hobbs, H. H. Birks, J. P. Briner, S. U. Holmgren, Ó. Ingólfsson, S. S. Kaushal, G. M. Miller, M. Pagani, J. E. Sarosi, and R. D. Vinebrooke. 2013. Stratigraphic expressions of the Holocene-Anthropocene transition revealed in sediments from remote lakes. Earth-Science Reviews 116:17-34.

Yanes, Y., M. Kowalewski, J. E. Ortiz, C. Castillo, T. de Torres, and J. de la Nuez. 2007. Scale and structure of time-averaging (age mixing) in terrestrial gastropod assemblages from Quaternary eolian deposits of the eastern Canary Islands. Palaeogeography, Palaeoclimatology, Palaeoecology 251:283-299.

Yasuhara, M., and H. Yamazaki. 2005. The impact of 150 years of anthropogenic pollution onthe shallow marine ostracode fauna, Osaka Bay, Japan. Marine Micropaleontology 55:63-74.

Yonge, C. M. 1946. On the habits and adaptations of Aloidis (Corbula) gibba. Journal of the Marine Biological Association of the United Kingdom 26:358-376.

Zanchettin, D., P. Traverso, and M. Tomasino. 2008. Po River discharges: a preliminary analysis of a 200 -year time series. Climatic Change 89:411-433.

Zonneveld, K. A., L. Chen, R. Elshanawany, H. W. Fischer, M. Hoins, M. I. Ibrahim, D. Pittauerova, and G. J. Versteegh. 2012. The use of dinoflagellate cysts to separate human-induced from natural variability in the trophic state of the Po River discharge plume over the last two centuries. Marine Pollution Bulletin 64:114-132.

Zuschin, M., and M. Stachowitsch. 2009. Epifauna-dominated benthic shelf assemblages: lessons from the modern Adriatic Sea. Palaios 24:211-221.

Zuschin, M., M. Harzhauser, and O. Mandic. 2007. The stratigraphic and sedimentologic framework of fine-scale faunal replacements in the Middle Miocene of the Vienna Basin (Austria). Palaios 22:285-295.

Zuschin, M., M. Harzhauser, B. Hengst, O. Mandic, and R. Roetzel. 2014. Long-term ecosystem stability in an Early Miocene estuary. Geology 42:7-10. 